\title{
The Impact of Superfund Sites on Local Property Values: Are All Sites the Same?
}

\author{
Katherine A. Kiel \\ and \\ Michael Williams
}

March 2005

\section{COLLEGE OF THE HOLY CROSS, DEPARTMENT OF ECONOMICS \\ FACULTY RESEARCH SERIES, WORKING PAPER NO. 05-05*}

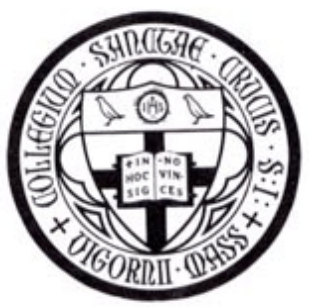

Department of Economics

College of the Holy Cross

Box 45A

Worcester, Massachusetts 01610

(508) 793-3362 (phone)

(508) 793-3710 (fax)

http://www.holycross.edu/departments/economics/website

*All papers in the Holy Cross Working Paper Series should be considered draft versions subject to future revision. Please do not quote or cite without permission of the authors. 


\title{
The Impact of Superfund Sites on Local Property Values: Are All Sites the Same?
}

\author{
Katherine A. Kiel ${ }^{\dagger}$ \\ College of the Holy Cross \\ and \\ Michael Williams ${ }^{\dagger+}$ \\ College of the Holy Cross
}

March 2005

\begin{abstract}
It seems an established empirical fact that Superfund sites lower local property values. Two recent literature reviews (Farber, 1998, Boyle and Kiel, 2001) report that published academic papers on the topic verify that point. The EPA's approach assumes that all sites negatively impact property values, and that the impact is similar for all sites. This paper examines 74 National Priorities List (NPL) sites in 13 U.S. counties in order to test these two implicit assumptions. Following the hedonic approach of Kiel (1995) and Kiel and McClain (1995), we find that some sites have the expected negative impact, while other sites have either no impact or a positive impact on local property values. We also consider the possibility of 'stigma' from sites by looking at those sites that have been cleaned during our sample period and find that some sites do appear to suffer from stigma, while others do not. We then use a metaanalysis approach to examine what factors affect the likelihood and extent of a decrease in property values near the sites. We find that larger sites in areas with fewer blue-collar workers are more likely to have the expected negative impact on local house prices.
\end{abstract}

JEL Classification Codes: Q51, Q53, Q58, R21

Keywords: Hedonic regressions, meta-analysis, property values

* The views expressed in this paper are those of the authors and do not necessarily reflect those of the U.S. EPA. We would like to thank the U.S. EPA for funding this research under a Cooperative Agreement.

${ }^{\dagger}$ Katherine A. Kiel, Department of Economics, College of the Holy Cross, Worcester, MA 01610-2395, 508-793-2743 (phone), 508-793-3710 (fax), kkiel@holycross.edu

${ }^{\dagger \dagger}$ Michael Williams, Department of Economics, College of the Holy Cross 
Introduction:

It seems an established empirical fact that Superfund sites lower local property values. Two recent literature reviews (Farber, 1998, Boyle and Kiel, 2001) report that published academic papers on the topic verify that point. The U.S. Environmental Protection Agency states that “[R]eview of a number of empirical studies indicates that the negative impact of Superfund sites on property values generally ranges from two to eight percent.” (Harris, 2003). These values can then be used to estimate the economic benefits of cleaning Superfund sites (Kiel and Zabel, 2001). The EPA’s approach assumes that all sites negatively impact property values, and that the impact is similar for all sites. This paper examines 74 National Priorities List (NPL) sites in 13 U.S. counties in order to test these two implicit assumptions.

Empirical studies generally use the hedonic approach (Rosen, 1974) to examine the impact of Superfund sites on local property values. The researchers regress various house and neighborhood characteristics on the sales price (or assessed value) of houses to uncover the effect of the presumed negative externalities. As stated above, published studies confirm that Superfund sites do indeed lower local house prices. However, it is possible that studies are only published if they find the 'expected' results (Smith and Huang 1993). Or it is possible that researchers choose to examine sites that are more notorious, and thus are likely to be regarded as negative externalities in the community, leading again to the 'expected' results. Given the variation in the types of Superfund sites, it is possible that different sites are less damaging to the local area or that they may even be seen as acceptable neighbors if, for example, they are sources of employment. 
This paper avoids these possible biases by examining all Superfund sites in the counties being studied to see whether the sites have the impacts reported in previous studies. The hedonic regressions that are estimated are kept as similar as possible in order to minimize the impact of different specifications on the results. We follow the methodology of Kiel (1995) and Kiel and McClain (1995) and estimate the regressions for various time periods defined by the role of the EPA in the identification and cleaning of the site. We find that some sites have the expected negative impact, while other sites have either no impact or a positive impact on local property values. We also consider the possibility of 'stigma' from sites by looking at those sites that have been cleaned during our sample period. We find that some sites do appear to suffer from stigma, while others do not.

We then use a meta-analysis approach to examine what factors affect the likelihood and extent of a decrease in property values near the sites. We find that larger sites in areas with fewer blue-collar workers are more likely to have the expected negative impact on local house prices.

This information should be helpful to the U.S. Environmental Protection Agency as they try to estimate the financial impact of cleaning such sites. It also sheds light on the Agency's ability to 'transfer' the results from previous studies to other sites that have not been studied.

\section{Literature Review:}

Previous empirical studies have concurred that Superfund sites do lower neighboring property values. Most of these papers use the hedonic approach to study the 
impact (see Freeman (2003) for a detailed discussion of hedonic theory). This technique assumes that houses are composites of the housing characteristics they embody (such as the number of bedrooms and lot size) as well as the neighborhood characteristics (such as distance from a toxic waste site). By regressing the various characteristics on the sales price or assessed value of the house, the estimated coefficients reveal the marginal impact of a change in that characteristic on the price of the house, holding all else constant. Thus both the sign and statistical significance of the coefficient measuring the possible impact of the Superfund site are of primary importance in these studies.

Farber (1998) reviews published papers that examined the impact of all undesirable land uses, including National Priorities List (NPL) sites. He reports on five papers on NPL sites: Adler et al (1982), Kohlhase (1991), Michaels and Smith (1990), Clark and Nieves (1994) and Greenberg and Hughes (1992). Adler et al examine a hazardous waste site in New Jersey in 1974 and report a negative impact of \$9,468 per mile (1993 dollars) on local house values up to 2.25 miles away. Kolhase studies a hazardous waste site in Texas and finds a statistically significant decrease of \$3,357 (1993 dollars) per mile in house prices that disappears once the site is declared by the EPA to be clean. Michaels and Smith look at hazardous waste sites in suburban Boston and find a statistically significant effect on property values that increases once the site is discovered (not all their sites are on the NPL during the period they study). They find differing impacts in areas that vary in housing quality as defined by real estate agents, reporting that prices increase by $\$ 3,310$ (1993 dollars) per mile further from the site. Clark and Nieves include the number of hazardous waste sites in a county in their regression on property values and find that the impact is not statistically significant. 
However, their study pre-dates Superfund. Greenberg and Hughes do not use hedonic regressions, but instead look at communities in New Jersey with and without Superfund sites and find that the communities with sites have lower rates of housing appreciation than those without such sites.

Kiel and Boyle survey hedonic studies that examine the impact of any type of environmental good on local house prices. They discuss six studies of NPL sites, three of which are also included in Farber's paper (Kolhase, Michaels and Smith, and Clark and Nieves). They also include Kiel (1995), Dale et al (1999) and Blomquist et al (1999). Kiel looks at two Superfund sites in Woburn, Massachusetts and finds a statistically significant impact on local house prices after the EPA announces that it is a Superfund site. The impact is an increase of $\$ 1,377$ (1982-3 dollars) per mile from the site. Dale et al study an NPL site in Texas and get the expected results of an increase in property values as distance from the site increases. Blomquist et al include the number of Superfund sites in the county in a regression on monthly housing expenditures and get a positive estimated coefficient that is statistically significant. Their study differs from most of the others in that it includes several other pollution measures which may be highly correlated with the number of hazardous waste sites.

Thus is seems to be a generally accepted fact that Superfund sites do lower local housing values. Harris (2003) states that the EPA believes this to be true, and that the EPA uses an estimate of a decrease in values of 2-8 percent. These assumptions appear to follow the evidence reported above, and can be used to estimate some of the economic benefits of cleaning up the sites. 
The authors of several of the hedonic studies have commented on whether or not Superfund sites appear to be 'stigmatized’ (e.g. Kolhase, 1991, McClusky and Rausser, 2003). If local house prices completely recover after the site has been cleaned, then it would appear that the sites do not have any stigma attached to them. If, however, prices near the site continue to remain low as seen by the coefficient on distance from the site remaining positive and statistically significant well after cleaning has occurred, then the site can be seen as suffering from stigma - even though it is clean people still prefer not to locate close to it. Kolhase reports that prices recover completely after the cleaning has occurred. McClusky and Rausser find that houses very close to the site do suffer from stigma over time, while those houses further away do not.

\section{Hedonic Model:}

In order to examine the impact of Superfund sites on local house prices, we use a unique data set developed by the U.S. EPA. The data set used in this analysis includes information on real estate transactions and characteristics at the housing unit level for 20 counties across the country from 1970 to $1990 .^{1} \quad$ Using Geographic Information System (GIS) protocols to measure distance between points, the housing data were linked to other observations in the data set. Data include (1) information on house sales in the county, including sales price and physical characteristics of each house; (2) block group level census data on income and racial characteristics of the area in 1970, 1980 and 1990; (3) environmental data on air quality, proximity to Superfund sites, proximity to hazardous

\footnotetext{
${ }^{1}$ The counties included are Alameda CA, Sacramento CA, San Diego CA, Santa Clara CA, Dade FL, Broward FL, Hillsborough FL, Pinellas FL, Fulton GA, DeKalb GA, Clayton GA, Cobb GA, St. Louis MO, Hamilton OH, Cuyahoga OH, Allegheny, PA, Fairfax VA, Arlington VA, King WA, and Milwaukee WI.
} 
waste sites, distance to the nearest water body; and (4) information on neighborhood amenities. The housing data were obtained from a vendor who geocoded the data so that other spatial data could be added. In the data set, Census data from 1970, 1980 and $1990^{2}$ were linked to the housing data by year of sale. The block group was used as the key for linking the appropriate demographic data with the house record. ${ }^{3}$

The data set also includes additional neighborhood variables, including landmark data on trailer courts, jails, prisons, educational institutions, employment centers, and national parks. Not all items are available for all counties, so these variables were not used in this study for the sake of consistency.

A number of pollution variables are also included in the full data set. In following most other researchers, we have chosen to include only information on Superfund sites. NPL variables available in the data set include information on the date of discovery, proposal, listing, and remedial action; total size of the site; distance in miles from the nearest NPL site to house; year waste treatment, storage, or disposal began at the site; and the year waste treatment, storage, or disposal ended at the site ${ }^{4}$.

We use the estimation approach developed by Kiel and McClain (1995) and Kiel (1995). Those studies assumed that changes in information about the site that were available to the public would change the impact of the site on local house prices. Thus

\footnotetext{
${ }^{2}$ The 1990 Census data were obtained from block group data files in the GNU compressed ArcInfo format from the EPA Intranet (epawww.epa.gov/STF3A/www/html/stf3a_mosaic.html) and from TigerLine 1994 files containing 1990 boundaries. An index field containing the state FIPS code, county FIPS code, census tract code, and census block group code was used to link the block group geospatial layers to the demographic tables containing the STF3A data.

${ }^{3}$ The spatial data were used to identify the 1990 block groups associated with a specific house address using the latitude/longitude available on the housing data record.

${ }^{4}$ NPL data were extracted from the RELAI Database. Additional data describing site locations, dates of actions, sizes of surrounding populations, risk values, and hazard index values, were derived from various sources: the RPM Survey, CERCLIS, the NPL Book, RID, SETS, and SNAP.
} 
the authors estimate hedonic regressions for several different time periods, as determined by the site's stage in the NPL or siting process. Following Kiel, we divide time into six periods: prior to discovery (the stage where the site is first considered by the EPA for possible listing), from discovery to the date the site is proposed for the NPL, from proposal to the date the site is officially listed on the NPL, from official listing to the official commencement of cleanup (as stated by the EPA), from the commencement of cleanup to the date the site is removed from the NPL, and finally the period following removal from the NPL. Many of the sites do not list an official beginning to the cleanup and/or are not removed from the NPL during our sample period, meaning that either or both of these latter two periods are not separately estimated for all sites.

Our hedonic regression is specified so as to be as similar as possible across the different county data sets (see Table 1 for variable definitions and some descriptive statistics for one site). The regression we estimate is:

$$
\begin{aligned}
& \text { Ln Pr ice }=a+b 1(\text { Bedrooms })+b 2(\text { Fullbath })+b 3(\text { Age })+b 4\left(\text { Age }^{2}\right)+b 5(\text { Bldgarea })+b 6(\text { Firedum }) \\
& +b 7(\text { Pooldum })+b 8(\text { Airdum })+b 9(\text { Parkdum })+b 10(\ln \text { Inc })+b 11(\text { Pownocc }) \\
& +b 12(\text { Pnwht })+b 13(\text { Punemp })+b 14(\text { Ppolcol })+b 15(\ln \text { Dist })+b 16(\text { Yxx })+\ldots . .
\end{aligned}
$$

The first five variables are included in all regressions, as are the relevant sale-year dummies.5 The amenity coefficients (b6 through b9) are not estimated for some regressions due to insufficient data. Insufficient census data (variables corresponding to coefficients b10 through b14) prevent their inclusion in a handful of regressions; these are indicated in Table 3 by stars placed in the "SITE" field.

5 In counties where building area is not available, the area of the entire lot is used. 
The twenty county-level data sets included information on 74 NPL sites in 13 of the counties. For a given site, only houses within three miles of the site are included, as numerous studies (e.g. Adler et al, Kohlhase, Kiel) have shown that an NPL site's effect on housing prices diminishes greatly at distances greater than three miles. To nullify the effect of tax differences amongst cities, the data set for a given NPL site is further limited to include data from only a single city, usually that in which the site is located. Also, due to the fact that a particular house is linked only to that NPL site which it is closest to, the simultaneous effects of multiple NPL sites upon any given area could not be gauged.

This preliminary cleaning of data eliminated 17 of the 74 sites from consideration. Some sites were excluded because the population density within their three-mile radius was too low, so that the site lacked a sufficiently large number of nearby house sales. Some sites located near to other sites possessed an insufficiently large number of observations because surrounding houses would be coded to the other, closer site.

Data for the remaining 57 sites are partitioned into the six time frames as mentioned previously. To eliminate potential outliers, we exclude the top and bottom five percent of house sales ranked by sales price. A procedure is also undertaken to eliminate data points that are particularly influential in the regression6. Since we are using cross-sectional data, procedures were undertaken to correct the standard errors for heteroskedasticity7. While not altering the estimator for the coefficient on NPLDIST, the correction does adjust the level of significance (shown as "Chi" in Table 2 and 3).

6 The SAS procedure is DFFITS which considers the change in the predicted sales price when each observation is dropped. If the statistic is greater than 2, the observation is dropped (SAS User's Guide, page 1419).

7 The SAS procedure is ACOV that estimates a covariance matrix under the assumption of heteroskedasticity. 


\section{Hedonic Results:}

In Tables 1 and 2 we report the summary statistics and the estimated coefficients from the hedonic regressions for one site, the Petroleum Products Corporation of Pembroke Park, Florida.8 This company’s site, based in Broward County, was selected because it is similar to many previous studies; it finds a positive and significant coefficient for NPL distance in the period following official NPL listing, a significance that disappears once cleanup is undertaken.

The site became polluted through the improper disposal of chemicals, such as sulfuric acid that was used to refine waste oil, as well as through leaks of the oil itself. The contamination, which occurred between 1952 and 1972, bore the added social cost of polluting the aquifer beneath the site, from which many surrounding towns derived their water supplies. Though the EPA succeeded in forcing the company to remove all of its drums, tanks, and other surface pollutants in 1987, the site has remained contaminated due to the seepage of the pollutants. This explains the positive significance of NPL distance on housing prices in the period between 1988 and 1992. Since 1987, the tactics used to recover the spilled oil and associated sludge have grown more elaborate, and even now the site has not been removed from the NPL. However, one could assume that, by 1993, local housing buyers considered the site to be clean enough to discount it from their buying decision, given the insignificance of the coefficient on distance to the NPL site in the final regression period.

\footnotetext{
8 Information on this site comes from the EPA website's various profiles of the site. The regression results for the other sites are available from the authors upon request.
} 
Since our primary focus is on the effect of the official NPL listing on housing prices, we present the estimated coefficients on the log of distance to the nearest site for each of the periods and each of the sites in Table 3 (complete results available from the authors upon request). Of the 57 regressions for these sites, 18 produce statistically significant $\left(\mathrm{Chi}^{2}<.05\right)$ and positive correlations between LNDIST and sale price, that is, increases in the log of distance from the site increased the homes' value after the site was listed on the NPL. Seven produce significantly negative correlations, and the remaining 32 are not statistically significant at the $5 \%$ level. While only 18 of the 57 sites create a clear decrease in housing prices once they were placed on the NPL, it should be noted that 33 of the 57 sites negatively affect prices at some point during their existence.

Overall, the adjusted $\mathrm{R}^{2} \mathrm{~s}$ for the regressions range from a low of -2.1266 in Hillsborough in 1983 (with 16 observations) to a high of 0.9921 in Times Beach in 1982 (with only 9 observations). Surprisingly, there does not seem to be a consistent replication of previous studies where the announcement by the EPA that a site would be placed on the NPL showed that house values were lower closer to the site. Some sites appear to not affect the local house values (e.g. the three sites in Allegheny), while others appear to be positive externalities that actually increase local house values (e.g. the Plant City and Valrico sites in Hillsborough).

For the 18 sites that produce positive and statistically significant coefficients on LNDIST, we report the dollar value and percentage impact on house prices (see Table 4). The former is calculated by multiplying the estimated coefficient by the ratio of the mean sales price to the mean distance in that county during that period. The percentage impacts range from a low of $0.94 \%$ to a high of $92.06 \%$ with a mean of $16.26 \%$ and a 
median between 6.34 to $7.52 \%$; thus the impacts can be greater than the two to eight percent range suggested by the EPA but that could be due to unusual sites.

Our data also allow us to examine our sites for possible stigma effects. We have four sites with data from all six periods; these are sites that have been 'cleaned' by the EPA during our sample period. The Hollingsworth Solderless Terminal in Fort Lauderdale was cleaned by 1992 so we have four years of house sales past that date. The site was seen as a negative externality in earlier periods, and remained so even after cleaning. Thus it would appear that this site suffers from stigma. This finding is in line with McCluskey and Rausser who reported that stigma existed within 1.2 miles of a cleaned site.

The Miami Gold Coast site was cleaned by 1991 so we have data for the following five years. This site was seen as a negative externality in the third period, but had no impact on house prices during the cleaning period nor during the period after that. In fact, it becomes a positive externality (statistically significant at the $5 \%$ level) once cleaning is complete. Thus this site does not appear to have any stigma attached to it. This is similar to Kohlhase’s finding that the premium for distance from such a site disappears once the site is cleaned.

Two other sites (Jibboom in Sacramento and Intel in Santa Clara) are never seen as either positive or negative externalities. Thus cleaning these sites appears to have no impact on local prices. Our results thus indicate that cleaning sites does not automatically remove stigma, although in some cases stigma might not be an issue. It appears that each site is unique in this regard. It appears that the two other previous 
studies that looked at stigma are correct for their sites, but that policy analysis must remember that sites can vary.

\section{Meta-Analysis:}

We find that some Superfund sites do have a negative effect on local property values, while others do not. In order to explore why this might be, we use a metaanalysis. This approach has been used by others (e.g. Smith and Huang (1993) who study hedonic models that examine the impact of air pollution on house values) to categorize groups of previous studies. We use the technique in a slightly different way; we have 57 sites that we have examined in a similar time frame and using a similar model specification. We then look to see if differences in the sites can help explain differences in the results.

The dependent variable in our meta-analytical model is a dummy variable (FOURTH) which is set equal to one for those sites whose coefficients on LNDIST were positive and significant for the period following official NPL listing, and is equal to zero if the estimated coefficient is negative or statistically insignificant. The independent variables include the size of the site, the nature of the site, the number of observations in the hedonic regression, and whether or not the site was ever perceived as a negative externality (as indicated by a positive and statistically significant coefficient on NPLDIST in any of the hedonic regressions from an earlier period) (see Table 5 for a complete list of variables and their means and standard deviations).

This model was applied to 55 of the 57 sites listed above (Moss-American in Milwaukee County and Valley Park TCE in St. Louis County lacked sufficient data 
regarding the size of the site), with 18 of the sites having been determined as having coefficients on LNDIST that are positive and significant. The regression is estimated using a probit model (see Table 6 for results.)

The meta-analysis reveals that the size of the site is positively related to obtaining a positive and statistically significant coefficient on distance from the site in the first regression, i.e. the larger the site, the more likely it is to have a negative influence on local sales prices. The number of observations is also positively related and marginally significant, i.e. sites with a greater number of nearby home sales (and thus sites with higher surrounding population densities) tend to detract more from housing values. Hedonic regressions with larger sample sizes are more likely to yield the expected results. Larger sample sizes in our case mean more houses sold within the three mile radius; the site is not likely to have another site near it. The adjusted $\mathrm{R}^{2}$ from the original hedonic regression is positively correlated, suggesting that houses whose prices better fit a standard model (one taking into account size, number of rooms, etc.) are more likely to have their values detracted by neighboring NPL sites.

The percentage of blue-collar residents in the county over the sample period is negatively correlated. This implies that the residents of blue-collar areas are less concerned with pricing in the effects of NPL proximity, possibly because their smaller incomes do not allow them the leverage to price this in. Sites which depressed housing values in periods prior to NPL listing tended to continue to depress them in the period following listing, implying that people purchasing homes in the prior periods already understood the disamenity presented by the sites and included this in their purchasing decision. 
Conclusions:

Based on the data generated through this study, it is the authors' opinions that, due to the widely varying affects that NPL sites have on nearby housing prices, it may not be in the best interests of the EPA to adopt a "one size fits all” formula for estimating the financial benefits from the cleanup of a given site. Any given NPL site possesses a body of characteristics that sets it apart from all others: its size, location, relative level of contamination, etc. It appears in many cases that a certain site's characteristics will not raise sufficient enough alarm in the mind of homebuyers for them to incorporate the site's existence into their pricing decisions. Indeed, in a small number of cases, the immediate proximity of the site may in fact be an attraction, reflected in negative significance on LNDIST for seven of fifty-seven sites in our regressions. Thus it is relatively clear, at least from our data, that not all NPL sites produce a negative effect on housing prices, nor do they necessarily produce similar impacts on local housing prices. 
Bibliography

Adler, K., Z. Cook, A. Ferguson, M. Vickers, R. Anderson and R. Dower. 1982. "The Benefits of Regulating Hazardous Disposal: Land Values as an Estimator.” U.S. Environmental Protection Agency, Washington DC.

Blomquist, G.C. M.C. Berger and J.P. Hoehn. 1988. "New Estimates of Quality of Life in Urban Areas.” American Economic Review 78(1):89-107.

Clark, D.C. and L.A. Nieves. 1994. "An Interregional Hedonic Analysis of Noxious Facility Impacts on Local Wages and Property Values." The Journal of Environmental Economics and Management 27(3):235-53.

Dale, L., J.C. Murdoch, M.A. Thayer and P.A. Waddell. 1999. "Do Property Values Rebound from Environmental Stigmas? Evidence from Dallas.” Land Economics 75(20:311-26.

Farber, S. 1998. "Undesirable Facilities and Property Values: A Summary of Empirical Studies.” Ecological Economics 24(1):1-14.

Freeman, A.M. 2003. The Measurement of Environmental and Resource Values. Second Edition. Resources for the Future, Washington D.C.

Greenberg, M. and J. Hughes. 1992. "The Impact of Hazardous Waste Superfund Sites on the Value of Houses Sold in New Jersey.” The Annals of Regional Science 26:147153.

Harris, John D. 2003. "Property Values, Stigma, and Superfund.” U.S. Environmental Protection Agency website.

Http://www.epa.gov/oerrpage/superfund/programs/recycle/overview/stigma.htm accessed $5 / 21 / 03$.

Kiel, K.A. 1995. "Measuring the Impact of the Discovery and Cleaning of Identified Hazardous Waste Sites on House Values.” Land Economics, 74(4):428-435.

Kiel, K.A. and M.A. Boyle. 2001. "A Survey of House Price Hedonic Studies of the Impact of Environmental Externalities” Journal of Real Estate Literature 9(2):117-144.

Kiel, K.A. and K.T. McClain. 1995. "House Prices During Siting Decision Stages: The Case of an Incinerator From Rumor Through Operation” The Journal of Environmental Economics and Management, 28(2): 241-255.

Kiel, K.A. and J.E. Zabel. 2001. "The Economic Benefits of Cleaning Superfund Sites”. Journal of Real Estate Finance and Economics 22(2/3):163-184. 
Kohlhase, J.E. 1991. “The Impact of Toxic Waste Sites on Housing Values.” Journal of Urban Economics 30:1-26.

McClusky, J.J. and G.C. Rausser. 2003. "Stigmatized Asset Value: Is it Temporary or Long-term?” Review of Economics and Statistics 85(2):076-285.

Michaels, R.G. and V.K. Smith. 1990. "Market Segmentation and Valuing Amenities with Hedonic Models: The Case of Hazardous Waste Sites.” Journal of Urban Economics 28:223-242.

Rosen, S. 1974. "Hedonic Prices and Implicit Markets: Product Differentiation in Pure Competition.” Journal of Political Economy 82:34-55.

SAS User's Manual

Smith, V. K and J. C. Huang. 1993. "Hedonic Models and Air Pollution: Twenty-Five Years and Counting.” Environmental and Resource Economics 3:381-394. 
Table 1

Variable Names for Hedonic Regressions

\begin{tabular}{|c|c|c|}
\hline Name & Definition & $\begin{array}{l}\text { Means and Standard } \\
\text { Deviations for Petroleum } \\
\text { Products Corp. } \\
\text { (Entire Period 1971-1996, } \\
\quad \mathrm{N}=8057 \text { ) }\end{array}$ \\
\hline LNPRICE & Log of Sales Price & $\begin{array}{c}\text { Mean = 11.021; } \\
\text { STD = .959 }\end{array}$ \\
\hline BEDROOMS & Number of Bedrooms & $\begin{array}{c}\text { Mean }=2.550 \\
\text { STD }=.638\end{array}$ \\
\hline FULLBATH & Number of Full Bathrooms & $\begin{array}{c}\text { Mean }=1.263 \\
\text { STD }=.976\end{array}$ \\
\hline AGE & Age of House & $\begin{aligned} \text { Mean } & =28.66 \\
\text { STD } & =13.94\end{aligned}$ \\
\hline AGE2 & Squared Age of House & $\begin{aligned} \text { Mean } & =1015.83 \\
\text { STD } & =1287.83\end{aligned}$ \\
\hline BLDGAREA & Building Area (square feet) & $\begin{array}{c}\text { Mean }=1659.63 \\
\text { STD }=641.22\end{array}$ \\
\hline FIREDUM & $=1$ if House has Fireplace & $\mathrm{N} / \mathrm{A}$ \\
\hline POOLDUM & $=1$ if House has Pool & $\begin{aligned} \text { Mean } & =.266 ; \\
\text { STD } & =.442\end{aligned}$ \\
\hline AIRDUM & $=1$ if House has Central Air & $\mathrm{N} / \mathrm{A}$ \\
\hline PARKDUM & $\begin{array}{c}=1 \text { if House has Garage or } \\
\text { Similar Structure }\end{array}$ & N/A \\
\hline LNINC & $\begin{array}{c}\text { Log of Median Family Income } \\
\text { of Census Tract }\end{array}$ & $\begin{array}{l}\text { Mean }=10.379 \\
\text { STD }=.430\end{array}$ \\
\hline POWNOCC & $\begin{array}{l}\text { Percent of Houses in Census } \\
\text { Tract that are Owner-Occupied }\end{array}$ & $\begin{aligned} \text { Mean } & =72.68 \\
\text { STD } & =19.86\end{aligned}$ \\
\hline PNWHT & $\begin{array}{c}\text { Percent of Non-white Residents } \\
\text { in Census Tract }\end{array}$ & $\begin{aligned} \text { Mean } & =15.31 \\
\text { STD } & =23.42\end{aligned}$ \\
\hline PUNEMP & $\begin{array}{c}\text { Unemployment Rate in Census } \\
\text { Tract }\end{array}$ & $\begin{aligned} \text { Mean } & =6.333 \\
\text { STD } & =7.394\end{aligned}$ \\
\hline PPOPCOL & $\begin{array}{c}\text { Percent of Census Tract } \\
\text { Residents with College } \\
\text { Education }\end{array}$ & $\begin{aligned} \text { Mean } & =33.57 \\
\text { STD } & =11.56\end{aligned}$ \\
\hline LNDIST & $\begin{array}{l}\text { Log of Distance from House to } \\
\text { Nearest NPL Site (in miles) }\end{array}$ & $\begin{aligned} \text { Mean } & =.702 \\
\text { STD } & =.362\end{aligned}$ \\
\hline YXX & Year of Sale Dummy Variables & $\begin{array}{c}\text { (Done for individual period } \\
\text { regressions) }\end{array}$ \\
\hline Name & Definition & $\begin{array}{l}\text { Means and Standard } \\
\text { Deviations for the Post- } \\
\text { Final Listing, Pre-Cleanup } \\
\text { Commencement Period }\end{array}$ \\
\hline
\end{tabular}




\begin{tabular}{|c|c|c|}
\hline & & $\begin{array}{l}(1988-1992, \\
N=2130)\end{array}$ \\
\hline LNPRICE & Log of Sales Price & $\begin{array}{l}\text { Mean = 11.272; } \\
\text { STD = .368 }\end{array}$ \\
\hline BEDROOMS & Number of Bedrooms & $\begin{aligned} \text { Mean } & =2.502 \\
\text { STD } & =.591\end{aligned}$ \\
\hline FULLBATH & Number of Full Bathrooms & $\begin{aligned} \text { Mean } & =1.199 \\
\mathrm{STD} & =.930\end{aligned}$ \\
\hline AGE & Age of House & $\begin{aligned} \text { Mean } & =30.83 \\
\text { STD } & =10.46\end{aligned}$ \\
\hline AGE2 & Squared Age of House & $\begin{aligned} \text { Mean } & =1059.73 \\
\text { STD } & =965.82\end{aligned}$ \\
\hline BLDGAREA & Building Area (square feet) & $\begin{aligned} \text { Mean } & =1582.69 \\
\text { STD } & =526.05\end{aligned}$ \\
\hline FIREDUM & $=1$ if House has Fireplace & N/A \\
\hline POOLDUM & $=1$ if House has Pool & $\begin{aligned} \text { Mean } & =.248 \\
\text { STD } & =.432\end{aligned}$ \\
\hline AIRDUM & $=1$ if House has Central Air & N/A \\
\hline PARKDUM & $\begin{array}{c}=1 \text { if House has Garage or } \\
\text { Similar Structure }\end{array}$ & N/A \\
\hline LNINC & $\begin{array}{l}\text { Log of Median Family Income } \\
\text { of Census Tract }\end{array}$ & $\begin{array}{l}\text { Mean }=10.464 \\
\text { STD }=.330\end{array}$ \\
\hline POWNOCC & $\begin{array}{l}\text { Percent of Houses in Census } \\
\text { Tract that are Owner-Occupied }\end{array}$ & $\begin{aligned} \text { Mean } & =71.45 \\
\text { STD } & =20.14\end{aligned}$ \\
\hline PNWHT & $\begin{array}{l}\text { Percent of Non-white Residents } \\
\text { in Census Tract }\end{array}$ & $\begin{aligned} \text { Mean } & =15.23 \\
\text { STD } & =21.19\end{aligned}$ \\
\hline PUNEMP & $\begin{array}{l}\text { Unemployment Rate in Census } \\
\text { Tract }\end{array}$ & $\begin{aligned} \text { Mean } & =6.335 \\
\text { STD } & =4.442\end{aligned}$ \\
\hline PPOPCOL & $\begin{array}{l}\text { Percent of Census Tract } \\
\text { Residents with College } \\
\text { Education }\end{array}$ & $\begin{array}{c}\text { Mean }=34.84 \\
\text { STD }=9.68\end{array}$ \\
\hline LNDIST & $\begin{array}{l}\text { Log of Distance from House to } \\
\text { Nearest NPL Site (in miles) }\end{array}$ & $\begin{aligned} \text { Mean } & =.700 \\
\text { STD } & =.352\end{aligned}$ \\
\hline Y88, Y89, Y90, Y91 & Year of Sale Dummy Variables & $\begin{aligned} & \text { Mean }(Y 88)=.183 ; \\
& \text { STD }(Y 88)=.386 \\
& \text { Mean }(Y 89)=.202 ; \\
& \text { STD }(Y 89)=.401 \\
& \text { Mean }(Y 90)=.203 ; \\
& \text { STD }(Y 90)=.402 \\
& \text { Mean }(Y 91)=.185 ; \\
& \text { STD }(Y 91)=.388 \\
& \text { *Approx. 22.8\% of houses } \\
& \text { sold in 1992 }(1-\text { Sum of } \\
& \text { above means) }\end{aligned}$ \\
\hline
\end{tabular}


TABLE 2

Hedonic Results for Petroleum Products Corporation

(Individual Periods)

NOTE: Since the top and bottom $5 \%$ of houses according to price are dropped for each individual period regression, the sum of the samples below makes up only $90 \%$ of the overall sample in Table 1.

\footnotetext{
Coefficient Estimates and Standard Deviations for the Pre-Discovery Period (1971-1982, $N=1796$, Adj. $R^{2}=.7681$,

Mean of LNPRICE $=10.632$, STD $=.432$ )
}

\begin{tabular}{|c|c|c|c|c|c|}
\hline VARIABLE & DF & ESTIMATE & STD & T-STAT & PROB. \\
\hline INTERCEP & 1 & 11.512924 & ๑. 26931736 & 42.749 & $\odot .0001$ \\
\hline BEDROOMS & 1 & 0.048993 & ๑. 01086856 & 4.508 & $\odot .00 \odot 1$ \\
\hline FULLBATH & 1 & -0.003994 & 0.00783223 & -0.510 & 0.6101 \\
\hline AGE & 1 & -0.010250 & $\odot .00140 \odot 28$ & -7.320 & $\odot .0001$ \\
\hline AGE2 & 1 & $\odot . \odot \odot \odot \odot 87612$ & $\odot . \odot \odot \odot \odot 1358$ & 6.451 & $\odot . \odot \odot \odot 1$ \\
\hline BLDGAREA & 1 & $\odot .00 \odot 270$ & $\odot .0 \odot \odot \odot 1410$ & 19.169 & $\odot .00 \odot 1$ \\
\hline POOLDUM & 1 & 0.088803 & 0.01345177 & 6.602 & $\odot .0 \odot \odot 1$ \\
\hline LNINC & 1 & -0.133457 & $\odot .02804901$ & -4.758 & $\odot . \odot \odot \odot 1$ \\
\hline POWNOCC & 1 & 0.001091 & $\odot .00042034$ & 2.594 & 0.0096 \\
\hline PNWHT & 1 & -0.001515 & $\odot . \odot \odot \odot 35154$ & -4.309 & $\odot . \odot \odot \odot 1$ \\
\hline PUNEMP & 1 & -0.002231 & $\odot .00498163$ & -0.448 & 0.6543 \\
\hline PPOPCOL & 1 & 0.013684 & $\odot . \odot \odot \odot 93197$ & 14.683 & $\odot .0 \odot \odot 1$ \\
\hline LNDIST & 1 & $\odot .020784$ & 0.01413737 & 1.470 & 0.1417 \\
\hline Y71 & 1 & -0.897903 & 0.03919512 & -22.909 & $\odot .0001$ \\
\hline Y72 & 1 & -0.822560 & $\odot .03605240$ & -22.816 & $\odot . \odot \odot \odot 1$ \\
\hline Y73 & 1 & -0.621989 & 0.03731395 & -16.669 & $\odot . \odot \odot \odot 1$ \\
\hline Y74 & 1 & -0.511855 & 0.03315575 & -15.438 & $\odot .0 \odot \odot 1$ \\
\hline Y75 & 1 & -0.541350 & 0.03253471 & -16.639 & $\odot . \odot \odot \odot 1$ \\
\hline Y76 & 1 & -0.544634 & 0.02966266 & -18.361 & $\odot . \odot \odot \odot 1$ \\
\hline Y77 & 1 & -0.484352 & $\odot .02724271$ & -17.779 & $\odot .0 \odot \odot 1$ \\
\hline Y78 & 1 & -0.372800 & 0.02687220 & -13.873 & $\odot .0 \odot \odot 1$ \\
\hline Y79 & 1 & -0.217260 & $\odot .02652509$ & -8.191 & $\odot .00 \odot 1$ \\
\hline Y80 & 1 & -0.080444 & 0.02828868 & -2.844 & $\odot .0 \odot 45$ \\
\hline Y81 & 1 & 0.020240 & 0.02929361 & 0.691 & 0.4897 \\
\hline
\end{tabular}

Coefficient Estimates and Standard Deviations for the Post-Discovery, Pre-Proposal Period (1983-1984, $\mathrm{N}=326, \mathrm{Adj} . \mathrm{R}^{2}=.7557$, Mean of LNPRICE $=11.096$, STD $=.370$ )

$\begin{array}{lcrrrr}\text { VARIABLE } & \text { DF } & \text { ESTIMATE } & \text { STD } & \text { T-STAT } & \text { PROB. } \\ & & & & & \\ \text { INTERCEP } & 1 & 10.004314 & 0.59363076 & 16.853 & 0.0001 \\ \text { BEDROOMS } & 1 & 0.026132 & 0.02450833 & 1.066 & 0.2871 \\ \text { FULLBATH } & 1 & 0.000563 & 0.01634697 & 0.034 & 0.9725 \\ \text { AGE } & 1 & -0.010733 & 0.00307839 & -3.487 & 0.0006 \\ \text { AGE2 } & 1 & 0.000124 & 0.00003136 & 3.959 & 0.0001\end{array}$




$\begin{array}{llrrrr}\text { BLDGAREA } & 1 & 0.00 \odot 312 & 0.00002946 & 10.607 & 0.0001 \\ \text { POOLDUM } & 1 & 0.117594 & 0.02956589 & 3.977 & 0.0001 \\ \text { LNINC } & 1 & 0.044112 & 0.06143920 & 0.718 & 0.4733 \\ \text { POWNOCC } & 1 & 0.000766 & 0.00081407 & 0.941 & 0.3473 \\ \text { PNWHT } & 1 & -0.002855 & 0.00087650 & -3.257 & 0.0012 \\ \text { PUNEMP } & 1 & -0.007525 & 0.00959813 & -0.784 & 0.4337 \\ \text { PPOPCOL } & 1 & 0.005139 & 0.00186979 & 2.749 & 0.0063 \\ \text { LNDIST } & 1 & 0.055472 & 0.03473437 & 1.597 & 0.1113 \\ \text { Y83 } & 1 & -0.014142 & 0.02085461 & -0.678 & 0.4982\end{array}$

\begin{tabular}{|c|c|c|c|c|c|}
\hline VARIABLE & DF & ESTIMATE & STD & T-STAT & PROB. \\
\hline INTERCEP & 1 & 10.048968 & ๑. 37615958 & 26.715 & $\odot .0 \odot \odot 1$ \\
\hline 3EDROOMS & 1 & 0.019635 & ๑.01485406 & 1.322 & $\odot .1866$ \\
\hline =ULLBATH & 1 & 0.024528 & 0.01041393 & 2.355 & 0.0187 \\
\hline AGE & 1 & $-\odot . \odot \odot 2 \odot 16$ & $\odot .0 \odot 184821$ & -1.091 & $\odot .2757$ \\
\hline AGE2 & 1 & $\odot . \odot \odot \odot \odot 14624$ & $\odot . \odot \odot \odot \odot 1732$ & 0.844 & $\odot .3988$ \\
\hline BLDGAREA & 1 & 0.000321 & $\odot .0 \odot \odot \odot 1869$ & 17.158 & $\odot .0 \odot \odot 1$ \\
\hline POOLDUM & 1 & ๑.112426 & 0.01644911 & 6.835 & $\odot .0001$ \\
\hline NINC & 1 & 0.025143 & 0.03907054 & 0.644 & 0.5201 \\
\hline POWNOCC & 1 & $\odot .00 \odot \odot 97534$ & 0.00047730 & 0.204 & 0.8381 \\
\hline PWHT & 1 & $-\odot .0 \odot \odot 258$ & $\odot .00046039$ & -0.561 & 0.5748 \\
\hline DUNEMP & 1 & -0.004782 & $\odot .00374900$ & -1.275 & 0.2025 \\
\hline PPOPCOL & 1 & 0.007429 & $\odot .00127804$ & 5.813 & $\odot .0001$ \\
\hline _NDIST & 1 & 0.095552 & 0.02091200 & 4.569 & $\odot .0001$ \\
\hline 185 & 1 & -0.092918 & 0.01645946 & -5.645 & $\odot .0001$ \\
\hline 886 & 1 & -0.044757 & ๑.01449740 & -3.087 & 0.0021 \\
\hline
\end{tabular}

Coefficient Estimates and Standard Deviations for the Post-Final Listing, Pre-Cleanup Commencement Period $(1988-1992, \mathrm{~N}=2130$,

Adj. $R^{2}=.7562$, Mean of LNPRICE $=11.272$, STD $=.368$ )

\begin{tabular}{llrrrr} 
VARIABLE & DF & ESTIMATE & \multicolumn{1}{c}{ STD } & T-STAT & PROB. \\
& & & & & \\
INTERCEP & 1 & 9.047306 & 0.24985358 & 36.210 & 0.0001 \\
BEDROOMS & 1 & -0.004950 & 0.00946402 & -0.523 & 0.6010 \\
FULLBATH & 1 & 0.020357 & 0.00667709 & 3.049 & 0.0023 \\
AGE & 1 & -0.006143 & 0.00114362 & -5.371 & 0.0001 \\
AGE2 & 1 & 0.000065423 & 0.00001190 & 5.499 & 0.0001 \\
BLDGAREA & 1 & 0.000341 & 0.00001210 & 28.174 & 0.0001 \\
POOLDUM & 1 & 0.107040 & 0.01077468 & 9.934 & 0.0001 \\
LNINC & 1 & 0.151099 & 0.02516218 & 6.005 & 0.0001 \\
POWNOCC & 1 & 0.000178 & 0.00028867 & 0.616 & 0.5380 \\
PNWHT & 1 & -0.001933 & 0.00030600 & -6.316 & 0.0001 \\
PUNEMP & 1 & 0.000770 & 0.00109417 & 0.703 & 0.4819 \\
PPOPCOL & 1 & 0.005578 & 0.00067102 & 8.312 & 0.0001 \\
LNDIST & 1 & 0.048643 & 0.01460021 & 3.332 & 0.0009 \\
Y88 & 1 & -0.073980 & 0.01396016 & -5.299 & 0.0001
\end{tabular}




$\begin{array}{llllll}\text { Y89 } & 1 & -0.043572 & 0.01322027 & -3.296 & 0.0010 \\ \text { Y90 } & 1 & -0.028191 & 0.01248206 & -2.259 & 0.0240 \\ \text { Y91 } & 1 & -0.015637 & 0.01264040 & -1.237 & 0.2162\end{array}$

\begin{tabular}{|c|c|c|c|c|c|}
\hline VARIABLE & DF & ESTIMATE & STD & T-STAT & PROB. \\
\hline INTERCEP & 1 & 9.576101 & 0.27220678 & 35.180 & 0.0001 \\
\hline BEDROOMS & 1 & 0.021141 & 0.01174153 & 1.800 & 0.0719 \\
\hline FULLBATH & 1 & 0.009435 & ๑.๑๑833579 & 1.132 & 0.2578 \\
\hline AGE & 1 & $-\odot .0 \odot 2501$ & $\odot .00265446$ & -0.942 & 0.3461 \\
\hline AGE2 & 1 & $-\odot .0 \odot \odot \odot 26425$ & $\odot . \odot \odot \odot \odot 4 \odot 26$ & -0.656 & 0.5117 \\
\hline BLDGAREA & 1 & 0.000326 & $\odot .0 \odot \odot \odot 16 \odot 5$ & 20.303 & 0.0001 \\
\hline POOLDUM & 1 & ๑.094520 & ๑.01398428 & 6.759 & 0.0001 \\
\hline LNINC & 1 & 0.119203 & ๑. 02648180 & 4.501 & 0.0001 \\
\hline POWNOCC & 1 & $\odot .000570$ & $\odot .00 \odot 31897$ & 1.788 & 0.0739 \\
\hline PNWHT & 1 & -0.002808 & $\odot .00 \odot 31427$ & -8.934 & 0.0001 \\
\hline PUNEMP & 1 & $-\odot .001020$ & $\odot .00 \odot 58124$ & -1.755 & 0.0795 \\
\hline PPOPCOL & 1 & 0.003399 & $\odot .00 \odot 58983$ & 5.762 & 0.0001 \\
\hline LNDIST & 1 & 0.009282 & 0.01848543 & 0.502 & 0.6156 \\
\hline Y93 & 1 & -0.075126 & ๑.02081898 & -3.609 & $\odot .00 \odot 3$ \\
\hline Y94 & 1 & -0.062662 & $\odot .02053307$ & -3.052 & 0.0023 \\
\hline Y95 & 1 & -0.017802 & $\odot .02001784$ & -0.889 & 0.3739 \\
\hline
\end{tabular}


SITE

COUNTY

ALAMEDA ALAMEDA ALAMEDA ALAMEDA

LIVERMORE

LIVERMORE

LIVERMORE

HARRISON TWP

ALAMEDA

ALLEGHENY

ALLEGHENY

HARRISON TWP

HARRISON TWP

JEFFERSON BORO

JEFFERSON BORO

JEFFERSON BORO

JEFFERSON BORO

NEVILLE ISLAND

NEVILLE ISLAND

NEVILLE ISLAND

NEVILLE ISLAND

${ }^{\text {*DAVIE }}$

${ }^{*}$ DAVIE

${ }^{*}$ DAVIE

${ }^{*}$ DAVIE

${ }^{\text {*DAVIE }}$

${ }^{{ }^{*} \mathrm{FT} . \text { LAUDERDALE (HOLLING...) }}$

${ }^{\star}$ FT. LAUDERDALE (HOLLING...)

${ }^{*}$ FT. LAUDERDALE (HOLLING...)

${ }^{*}$ FT. LAUDERDALE (HOLLING...)

${ }^{*}$ FT. LAUDERDALE (HOLLING...)

FT. LAUDERDALE (WINGATE...)

FT. LAUDERDALE (WINGATE...)

FT. LAUDERDALE (WINGATE...)

FT. LAUDERDALE (WINGATE...)

PEMBROKE PARK

PEMBROKE PARK

TABLE 3

CITY TIME N ADJ R ${ }^{2}$ LNDIST Chi²Prob.

\begin{tabular}{|c|c|c|c|c|c|}
\hline LIVERMORE & $71-80$ & 124 & 0.5913 & -0.0422 & 0.7443 \\
\hline LIVERMORE & $81-84$ & 112 & 0.2682 & 0.1510 & 0.5361 \\
\hline LIVERMORE & $85-87$ & 203 & 0.3358 & -0.0637 & 0.5232 \\
\hline LIVERMORE & $88-92$ & 762 & 0.5765 & -0.0347 & 0.3760 \\
\hline LIVERMORE & $93-96$ & 611 & 0.4971 & -0.0223 & 0.5723 \\
\hline NATRONA HEIGHTS & $74-79$ & 108 & 0.3189 & -0.0928 & 0.4814 \\
\hline NATRONA HEIGHTS & $80-81$ & 26 & 0.8165 & -0.3537 & 0.0012 \\
\hline NATRONA HEIGHTS & $82-83$ & 18 & 0.8562 & 0.6442 & 0.0000 \\
\hline NATRONA HEIGHTS & $84-94$ & 169 & 0.5457 & 0.0556 & 0.2822 \\
\hline CLAIRTON & $74-78$ & 57 & 0.6751 & 0.8908 & 0.0004 \\
\hline CLAIRTON & $79-82$ & 30 & 0.8444 & -2.0938 & 0.0000 \\
\hline CLAIRTON & 83 & $8^{*}$ & N/A & $\mathrm{N} / \mathrm{A}$ & N/A \\
\hline CLAIRTON & $84-94$ & 185 & 0.5539 & 0.1106 & 0.3527 \\
\hline CORAOPOLIS & $73-78$ & 93 & 0.3554 & 0.3713 & 0.0412 \\
\hline CORAOPOLIS & $79-89$ & 150 & 0.5656 & -0.2845 & 0.1319 \\
\hline CORAOPOLIS & 90 & 18 & 0.8707 & 0.7900 & 0.0656 \\
\hline CORAOPOLIS & $91-94$ & 101 & 0.8074 & -0.0216 & 0.7349 \\
\hline DAVIE & $71-79$ & 64 & 0.4359 & -0.0639 & 0.6596 \\
\hline DAVIE & $80-81$ & 16 & 0.6542 & 0.0300 & 0.9019 \\
\hline DAVIE & $82-83$ & $6^{*}$ & $\mathrm{~N} / \mathrm{A}$ & N/A & N/A \\
\hline DAVIE & $84-87$ & 423 & 0.3798 & -0.0551 & 0.4059 \\
\hline DAVIE & $88-96$ & 1372 & 0.6737 & -0.0812 & 0.0009 \\
\hline FT. LAUDERDALE & $71-80$ & 1003 & 0.7888 & 0.0948 & 0.0000 \\
\hline FT . LAUDERDALE & 81 & 61 & 0.6835 & 0.0349 & 0.5746 \\
\hline FT. LAUDERDALE & $82-83$ & 158 & 0.8362 & 0.0229 & 0.4887 \\
\hline FT. LAUDERDALE & 84-87 & 646 & 0.8277 & 0.0638 & 0.0000 \\
\hline FT . LAUDERDALE & $88-92^{*}$ & 1206 & 0.8042 & 0.1130 & 0.0000 \\
\hline FT. LAUDERDALE & $93-96$ & 1408 & 0.7420 & 0.1553 & 0.0000 \\
\hline FT. LAUDERDALE & $71-81$ & 1330 & 0.5752 & 0.0006 & 0.9768 \\
\hline FT. LAUDERDALE & $82-87$ & 703 & 0.4376 & -0.0061 & 0.8547 \\
\hline FT. LAUDERDALE & $88-89$ & 399 & 0.5531 & 0.0760 & 0.0358 \\
\hline FT. LAUDERDALE & $90-96$ & 1815 & 0.2792 & 0.0770 & 0.0005 \\
\hline HOLLYWOOD & $71-82$ & 1796 & 0.7681 & 0.0208 & 0.1170 \\
\hline HOLLYWOOD & $83-84$ & 326 & 0.7557 & 0.0555 & 0.1174 \\
\hline
\end{tabular}




\begin{tabular}{|c|c|c|c|c|c|c|c|}
\hline PEMBROKE PARK & BROWARD & HOLLYWOOD & $85-87$ & 889 & 0.7500 & 0.0956 & 0.0000 \\
\hline PEMBROKE PARK & BROWARD & HOLLYWOOD & 88-92 & 2130 & 0.7562 & 0.0486 & 0.0066 \\
\hline PEMBROKE PARK & BROWARD & HOLLYWOOD & $93-96$ & 2124 & 0.6359 & 0.0093 & 0.6439 \\
\hline POMPANO BEACH (CHEM...) & BROWARD & POMPANO BEACH & $71-78$ & 139 & 0.6838 & 0.2258 & 0.4840 \\
\hline POMPANO BEACH (CHEM...) & BROWARD & POMPANO BEACH & $79-87$ & 192 & 0.6384 & 0.6995 & 0.0123 \\
\hline POMPANO BEACH (CHEM...) & BROWARD & POMPANO BEACH & $88-89$ & 86 & 0.8623 & 1.4507 & 0.0020 \\
\hline POMPANO BEACH (CHEM...) & BROWARD & POMPANO BEACH & $90-92$ & 143 & 0.5626 & 1.7620 & 0.0144 \\
\hline POMPANO BEACH (CHEM...) & BROWARD & POMPANO BEACH & $93-96$ & 210 & 0.4650 & 0.3755 & 0.3060 \\
\hline POMPANO BEACH (WILSON...) & BROWARD & POMPANO BEACH & $71-85$ & 316 & 0.7691 & 0.3867 & 0.0000 \\
\hline POMPANO BEACH (WILSON...) & BROWARD & POMPANO BEACH & $86-87$ & 101 & 0.4962 & 0.1103 & 0.2565 \\
\hline POMPANO BEACH (WILSON...) & BROWARD & POMPANO BEACH & 88 & 51 & 0.7459 & 0.1030 & 0.1414 \\
\hline POMPANO BEACH (WILSON...) & BROWARD & POMPANO BEACH & $89-91$ & 187 & 0.5967 & 0.2390 & 0.0006 \\
\hline POMPANO BEACH (WILSON...) & BROWARD & POMPANO BEACH & $92-96$ & 421 & 0.5657 & 0.2987 & 0.0000 \\
\hline CLEVELAND & CUYAHOGA & NON-NPL SITE & $\mathrm{N} / \mathrm{A}$ & $\mathrm{N} / \mathrm{A}$ & $\mathrm{N} / \mathrm{A}$ & $\mathrm{N} / \mathrm{A}$ & $\mathrm{N} / \mathrm{A}$ \\
\hline HIALEAH (B\&B ...) & DADE & HIALEAH & $71-85$ & 2395 & 0.8001 & 0.0220 & 0.0532 \\
\hline HIALEAH (B\&B . . .) & DADE & HIALEAH & $86-87$ & 469 & 0.2455 & 0.0683 & 0.0009 \\
\hline HIALEAH (B\&B ...) & DADE & HIALEAH & $88-90$ & 557 & 0.3508 & 0.0228 & 0.1791 \\
\hline HIALEAH (B\&B . . .) & DADE & HIALEAH & $91-96$ & 1012 & 0.4024 & 0.0422 & 0.0071 \\
\hline HIALEAH (NORTHWEST . . . ) & DADE & IO & $\mathrm{N} / \mathrm{A}$ & $\mathrm{N} / \mathrm{A}$ & $\mathrm{N} / \mathrm{A}$ & $\mathrm{N} / \mathrm{A}$ & $\mathrm{N} / \mathrm{A}$ \\
\hline HIALEAH (STANDARD . . . ) & DADE & HIALEAH & $71-81$ & 654 & 0.6200 & -0.0146 & 0.5098 \\
\hline HIALEAH (STANDARD ....) & DADE & HIALEAH & $82-87$ & 370 & 0.2717 & -0.0473 & 0.1127 \\
\hline HIALEAH (STANDARD ....) & DADE & HIALEAH & $88-89$ & 148 & 0.2445 & -0.0680 & 0.4507 \\
\hline HIALEAH (STANDARD ....) & DADE & HIALEAH & $90-93$ & 225 & 0.5050 & 0.0081 & 0.7108 \\
\hline HIALEAH (STANDARD ....) & DADE & HIALEAH & $94-96$ & 161 & 0.1133 & -0.1163 & 0.1959 \\
\hline HOMESTEAD AFB & DADE & I0 & $\mathrm{N} / \mathrm{A}$ & $\mathrm{N} / \mathrm{A}$ & $\mathrm{N} / \mathrm{A}$ & $\mathrm{N} / \mathrm{A}$ & $\mathrm{N} / \mathrm{A}$ \\
\hline MEDLEY & DADE & HIALEAH & $71-79$ & 246 & 0.6880 & 0.2129 & 0.0230 \\
\hline MEDLEY & DADE & HIALEAH & $80-83$ & 141 & 0.5177 & 0.5091 & 0.1584 \\
\hline MEDLEY & DADE & HIALEAH & 84 & 49 & 0.7656 & 0.1665 & 0.5250 \\
\hline MEDLEY & DADE & HIALEAH & $85-86$ & 160 & 0.7262 & 0.3556 & 0.0015 \\
\hline MEDLEY & DADE & HIALEAH & $87-96$ & 3059 & 0.8186 & 0.0800 & 0.0000 \\
\hline MIAMI (AIRCO ....) & DADE & MIAMI & $71-80$ & 853 & 0.3712 & 0.2012 & 0.0000 \\
\hline (AIRCO...) & DADE & MIAMI & $81-87$ & 640 & 0.4339 & 0.1706 & 0.0000 \\
\hline$($ AIRCO ....) & DADE & MIAMI & $88-89$ & 204 & 0.3987 & 0.0868 & 0.0610 \\
\hline$($ AIRCO ... $)$ & DADE & MIAMI & $90-96$ & 737 & 0.3571 & 0.0299 & 0.3449 \\
\hline (ANACONDA...) & DADE & MIAMI & $71-80$ & 1794 & 0.4547 & -0.0461 & 0.0027 \\
\hline (ANACONDA... ) & DADE & MIAMI & $81-89$ & 1410 & 0.3046 & -0.0134 & 0.6205 \\
\hline (ANACONDA....) & DADE & MIAMI & 90 & 175 & 0.3163 & 0.0397 & 0.3025 \\
\hline (ANACONDA....) & DADE & MIAMI & $91-96$ & 954 & 0.3311 & -0.0042 & 0.8361 \\
\hline
\end{tabular}




\begin{tabular}{|c|c|c|c|c|c|c|c|}
\hline *MIAMI (GOLD COAST ... ) & DADE & MIAMI & $71-80$ & 4176 & 0.6731 & 0.0232 & 0.0000 \\
\hline ॠMIAMI (GOLD COAST . . .) & DADE & MIAMI & 81 & 282 & 0.1984 & 0.0064 & 0.8230 \\
\hline “MIAMI (GOLD COAST ....) & DADE & MIAMI & $82-83$ & 631 & 0.3199 & -0.0133 & 0.3860 \\
\hline *MIAMI (GOLD COAST ....) & DADE & MIAMI & $84-88$ & 2815 & 0.4288 & 0.0156 & 0.0140 \\
\hline ॠMIAMI (GOLD COAST . . . ) & DADE & MIAMI & $89-91^{*}$ & 1483 & 0.6263 & -0.0012 & 0.8657 \\
\hline *MIAMI (GOLD COAST ....) & DADE & MIAMI & $92-96$ & 2454 & 0.4868 & -0.0147 & 0.0507 \\
\hline MIAMI (MIAMI DRUM....) & DADE & IO & $\mathrm{N} / \mathrm{A}$ & $\mathrm{N} / \mathrm{A}$ & $\mathrm{N} / \mathrm{A}$ & $\mathrm{N} / \mathrm{A}$ & $\mathrm{N} / \mathrm{A}$ \\
\hline MIAMI (VARSOL SPILL) & DADE & MIAMI & $71-79$ & 444 & 0.6015 & 0.2356 & 0.0055 \\
\hline MIAMI (VARSOL SPILL) & DADE & MIAMI & $80-81$ & 58 & 0.3227 & -0.0530 & 0.5597 \\
\hline MIAMI (VARSOL SPILL) & DADE & MIAMI & $82-84$ * & 107 & 0.1111 & 0.1171 & 0.2598 \\
\hline MIAMI (VARSOL SPILL) & DADE & MIAMI & $85-96$ & 699 & 0.5279 & 0.0143 & 0.6145 \\
\hline NORTH MIAMI (MUNISPORT . . . ) & DADE & NORTH MIAMI & $71-78$ & 357 & 0.7487 & 0.0416 & 0.3245 \\
\hline NORTH MIAMI (MUNISPORT . . .) & DADE & NORTH MIAMI & $79-82$ & 233 & 0.6854 & -0.0237 & 0.7256 \\
\hline NORTH MIAMI (MUNISPORT . . .) & DADE & NORTH MIAMI & 83 & 70 & 0.6948 & 0.2428 & 0.1570 \\
\hline NORTH MIAMI (MUNISPORT...) & DADE & NORTH MIAMI & $84-94$ & 1642 & 0.7916 & -0.1355 & 0.0000 \\
\hline NORTH MIAMI (MUNISPORT . . . ) & DADE & NORTH MIAMI & $95-96$ & 283 & 0.5810 & 0.0032 & 0.9787 \\
\hline NORTH MIAMI BEACH & $D A D E$ & MIAMI & $71-84$ & 3315 & 0.7394 & -0.0172 & 0.0192 \\
\hline NORTH MIAMI BEACH & DADE & MIAMI & $85-87$ & 1510 & 0.5630 & -0.0058 & 0.5572 \\
\hline NORTH MIAMI BEACH & DADE & MIAMI & $88-89$ & 1322 & 0.6029 & -0.0091 & 0.3486 \\
\hline NORTH MIAMI BEACH & DADE & MIAMI & $90-96$ & 3634 & 0.5723 & -0.0073 & 0.2665 \\
\hline PRINCETON & $D A D E$ & HOMESTEAD & $71-78$ & 214 & 0.6590 & -0.2176 & 0.0001 \\
\hline PRINCETON & DADE & HOMESTEAD & $79-87$ & 340 & 0.5387 & -0.1685 & 0.0017 \\
\hline PRINCETON & DADE & HOMESTEAD & $88-90$ & 241 & 0.4290 & -0.0670 & 0.0181 \\
\hline PRINCETON & DADE & HOMESTEAD & $91-92^{*}$ & 201 & 0.7360 & 0.0421 & 0.2155 \\
\hline PRINCETON & DADE & HOMESTEAD & $93-96$ & 392 & 0.1859 & 0.0507 & 0.3125 \\
\hline FERNALD & HAMILTON & I0 & $\mathrm{N} / \mathrm{A}$ & $\mathrm{N} / \mathrm{A}$ & $\mathrm{N} / \mathrm{A}$ & $\mathrm{N} / \mathrm{A}$ & $\mathrm{N} / \mathrm{A}$ \\
\hline READING & HAMILTON & CINCINNATI & $76-78$ & 409 & 0.7145 & -0.0030 & 0.9059 \\
\hline READING & HAMILTON & CINCINNATI & $79-82$ & 349 & 0.4164 & -0.0041 & 0.9278 \\
\hline READING & HAMILTON & CINCINNATI & 83 & 196 & 0.6877 & -0.0052 & 0.9362 \\
\hline READING & HAMILTON & CINCINNATI & 84-91 & 2580 & 0.6341 & 0.0347 & 0.0111 \\
\hline READING & HAMILTON & CINCINNATI & $92-95$ & 1561 & 0.5943 & 0.1058 & 0.0000 \\
\hline$\overline{\text { PLANT CITY }}$ & HILLSBOROUGH & PLANT CITY & $71-79$ & 402 & 0.3759 & 0.1514 & 0.0256 \\
\hline PLANT CITY & HILLSBOROUGH & PLANT CITY & $80-82$ & 158 & 0.2790 & -0.2947 & 0.0323 \\
\hline PLANT CITY & HILLSBOROUGH & PLANT CITY & 83 & 61 & 0.6133 & -0.5871 & 0.0387 \\
\hline PLANT CITY & HILLSBOROUGH & PLANT CITY & $84-91$ & 1322 & 0.4961 & -0.1921 & 0.0001 \\
\hline PLANT CITY & HILLSBOROUGH & PLANT CITY & $92-95$ & 1038 & 0.4049 & -0.0873 & 0.1909 \\
\hline SEFFNER & HILLSBOROUGH & SEFFNER & $71-79$ & 455 & 0.5125 & 0.1513 & 0.0381 \\
\hline SEFFNER & HILLSBOROUGH & SEFFNER & $80-81$ & 111 & 0.5080 & 0.3659 & 0.0018 \\
\hline
\end{tabular}




\begin{tabular}{|c|c|c|c|c|c|c|c|}
\hline SEFFNER & HILLSBOROUGH & SEFFNER & $82-83$ & 111 & 0.4126 & 0.3810 & 0.0647 \\
\hline SEFFNER & HILLSBOROUGH & SEFFNER & $84-92$ & 1142 & 0.2227 & 0.1096 & 0.0709 \\
\hline TAMPA (62ND STREET... ) & HILLSBOROUGH & TAMPA & $71-82$ & 244 & 0.5039 & 0.4806 & 0.0000 \\
\hline TAMPA (62ND STREET ... ) & HILLSBOROUGH & TAMPA & 83 & 16 & -2.1266 & 0.5197 & 0.9382 \\
\hline TAMPA (62ND STREET... ) & HILLSBOROUGH & TAMPA & 84-92 & 353 & 0.1886 & 0.0385 & 0.6899 \\
\hline TAMPA (62ND STREET... ) & HILLSBOROUGH & TAMPA & $93-96$ * & 201 & 0.2620 & 0.6755 & 0.0011 \\
\hline TAMPA (HELENA. .. ) & HILLSBOROUGH & TAMPA & $71-81$ & 1767 & 0.4089 & 0.0145 & 0.8385 \\
\hline TAMPA (HELENA....) & HILLSBOROUGH & TAMPA & $82-91$ & 2867 & 0.4718 & -0.0422 & 0.4100 \\
\hline TAMPA (HELENA... .) & HILLSBOROUGH & TAMPA & 92 & 539 & 0.4829 & -0.1037 & 0.4721 \\
\hline TAMPA (HELENA ....) & HILLSBOROUGH & TAMPA & $93-96$ & 1975 & 0.5223 & 0.0549 & 0.3856 \\
\hline *TAMPA (KASSAUF ... .) & HILLSBOROUGH & TAMPA & $71-80$ & 790 & 0.3993 & 0.0777 & 0.2125 \\
\hline *TAMPA (KASSAUF... ) & HILLSBOROUGH & TAMPA & 81 & 51 & 0.3419 & -0.6944 & 0.0065 \\
\hline *TAMPA (KASSAUF . . . ) & HILLSBOROUGH & TAMPA & $82-83$ & 115 & 0.1205 & 0.0964 & 0.5612 \\
\hline *TAMPA (KASSAUF ... .) & HILLSBOROUGH & TAMPA & $84-92$ & 919 & 0.1672 & 0.0849 & 0.1552 \\
\hline${ }^{\star}$ TAMPA (KASSAUF . . . ) & HILLSBOROUGH & TAMPA & $93-96^{*}$ & 494 & 0.0774 & 0.1279 & 0.0826 \\
\hline TAMPA (PEAK OIL ... ) & HILLSBOROUGH & TAMPA & $71-75$ & 766 & 0.3467 & -0.0218 & 0.7439 \\
\hline TAMPA (PEAK OIL....) & HILLSBOROUGH & TAMPA & $76-83$ & 1581 & 0.3758 & 0.0479 & 0.2096 \\
\hline TAMPA (PEAK OIL....) & HILLSBOROUGH & TAMPA & 84 & 301 & 0.3250 & 0.2910 & 0.0141 \\
\hline TAMPA (PEAK OIL ....) & HILLSBOROUGH & TAMPA & $85-86$ & 635 & 0.3014 & 0.1041 & 0.0852 \\
\hline TAMPA (PEAK OIL...) & HILLSBOROUGH & TAMPA & $87-96^{*}$ & 4795 & 0.3850 & -0.0522 & 0.0005 \\
\hline TAMPA (REEVES . .. ) & HILLSBOROUGH & I0 & $\mathrm{N} / \mathrm{A}$ & $\mathrm{N} / \mathrm{A}$ & $\mathrm{N} / \mathrm{A}$ & $\mathrm{N} / \mathrm{A}$ & $\mathrm{N} / \mathrm{A}$ \\
\hline VALRICO & HILLSBOROUGH & VALRICO & $71-84$ & 272 & 0.5207 & 0.0021 & 0.9956 \\
\hline VALRICO & HILLSBOROUGH & VALRICO & 85 & 32 & 0.8620 & -0.2029 & 0.4440 \\
\hline VALRICO & HILLSBOROUGH & VALRICO & $86-89$ & 328 & 0.4122 & 0.0276 & 0.9266 \\
\hline VALRICO & HILLSBOROUGH & VALRICO & 90-92 & 263 & 0.4494 & -0.5629 & 0.0257 \\
\hline VALRICO & HILLSBOROUGH & VALRICO & $93-96^{*}$ & 377 & 0.2973 & -0.0174 & 0.9244 \\
\hline KENT (MIDWAY LANDFILL) & KING & KENT & $77-80$ & 131 & 0.5967 & 0.0639 & 0.1324 \\
\hline KENT (MIDWAY LANDFILL) & KING & KENT & $81-84$ & 95 & 0.7192 & -0.0246 & 0.5916 \\
\hline KENT (MIDWAY LANDFILL) & KING & KENT & 85 & 39 & 0.6805 & 0.0406 & 0.4364 \\
\hline KENT (MIDWAY LANDFILL) & KING & KENT & $86-96$ & 741 & 0.6963 & 0.0374 & 0.0076 \\
\hline${ }^{*}$ KENT (SEATTLE . . . ) & KING & KENT & $77-80$ & 61 & 0.6668 & 0.0622 & 0.0420 \\
\hline${ }^{\star}$ KENT (SEATTLE ... .) & KING & KENT & $81-87$ & 127 & 0.4571 & 0.0344 & 0.2038 \\
\hline *KENT (SEATTLE . . . ) & KING & KENT & $88-90$ & 93 & 0.6793 & 0.0905 & 0.0016 \\
\hline * KENT (SEATTLE . . . ) & KING & KENT & $91-94$ * & 227 & 0.6480 & 0.0231 & 0.1416 \\
\hline${ }^{\star}{ }^{\prime}$ KENT (SEATTLE . . . ) & KING & KENT & $95-96$ & 45 & 0.6182 & 0.0102 & 0.7124 \\
\hline KENT (WESTERN . . . ) & KING & KENT & $77-80$ & 109 & 0.6523 & -0.1461 & 0.0163 \\
\hline KENT (WESTERN . . . .) & KING & KENT & $81-82$ & 26 & 0.4887 & -0.1059 & 0.3408 \\
\hline KENT (WESTERN . . . . ) & KING & KENT & 83 & 31 & 0.4440 & -0.0674 & 0.6569 \\
\hline
\end{tabular}




\begin{tabular}{|c|c|c|c|c|c|c|c|}
\hline (WESTERN . . . ) & KING & KENT & 84 * & 44 & 0.5632 & -0.1445 & 0.3534 \\
\hline KENT (WESTERN . . .) & KING & KENT & $85-96$ & 1291 & 0.7095 & -0.2219 & 0.0000 \\
\hline${ }^{\star}$ MAPLE VALLEY & KING & ISSAQUAH & $77-79$ & 61 & 0.6421 & 0.0944 & 0.3716 \\
\hline *MAPLE VALLEY & KING & ISSAQUAH & $80-83$ & 54 & 0.6066 & 0.1311 & 0.5842 \\
\hline *MAPLE VALLEY & KING & ISSAQUAH & 84 & 18 & 0.8430 & -1.4460 & 0.0000 \\
\hline *MAPLE VALLEY & KING & ISSAQUAH & $85-96$ & 511 & 0.5695 & 0.0375 & 0.4765 \\
\hline RENTON & KING & RENTON & $77-80$ & 473 & 0.5855 & 0.0575 & 0.1352 \\
\hline RENTON & KING & RENTON & $81-87$ & 944 & 0.5936 & -0.0019 & 0.8936 \\
\hline RENTON & KING & RENTON & $88-89$ & 533 & 0.5385 & 0.0049 & 0.8040 \\
\hline RENTON & KING & RENTON & $90-96$ & 2262 & 0.6361 & -0.0069 & 0.3734 \\
\hline SEATTLE (HARBOR . . . ) & KING & SEATTLE & $77-79$ & 225 & 0.3676 & -0.1082 & 0.2028 \\
\hline SEATTLE (HARBOR . . . ) & KING & SEATTLE & $80-82$ & 134 & 0.4165 & -0.0475 & 0.6820 \\
\hline SEATTLE (HARBOR . . . ) & KING & SEATTLE & 83 & 61 & 0.6938 & 0.1558 & 0.2044 \\
\hline SEATTLE (HARBOR . . . ) & KING & SEATTLE & $84-96$ & 2215 & 0.5218 & 0.1270 & 0.0000 \\
\hline SEATTLE (PAC-SOUND RES . ) & KING & SEATTLE & $77-78$ & 144 & 0.4964 & -0.0459 & 0.3400 \\
\hline SEATTLE (PAC-SOUND RES.) & KING & SEATTLE & $79-92$ & 2287 & 0.6491 & -0.0553 & 0.0000 \\
\hline SEATTLE (PAC-SOUND RES.) & KING & SEATTLE & $93-94$ & 746 & 0.3469 & -0.0784 & 0.0001 \\
\hline SEATTLE (PAC-SOUND RES.) & KING & SEATTLE & $95-96$ & 453 & 0.3370 & -0.0447 & 0.0635 \\
\hline *FRANKLIN & MILWAUKEE & MILWAUKEE & $71-83$ & 498 & 0.5675 & 0.0862 & 0.0596 \\
\hline *FRANKLIN & MILWAUKEE & MILWAUKEE & 84 & 50 & 0.5926 & -0.0268 & 0.5672 \\
\hline *FRANKLIN & MILWAUKEE & MILWAUKEE & 85 & 54 & 0.6238 & 0.0874 & 0.0078 \\
\hline *FRANKLIN & MILWAUKEE & MILWAUKEE & $86-92$ & 532 & 0.3835 & 0.0149 & 0.5122 \\
\hline *FRANKLIN & MILWAUKEE & MILWAUKEE & $93-95$ & 233 & 0.5852 & -0.0112 & 0.6323 \\
\hline MILWAUKEE & MILWAUKEE & MILWAUKEE & $71-80$ & 354 & 0.7128 & -0.1275 & 0.1234 \\
\hline MILWAUKEE & MILWAUKEE & MILWAUKEE & $81-83$ & 60 & 0.6721 & -0.2958 & 0.0831 \\
\hline MILWAUKEE & MILWAUKEE & MILWAUKEE & 84 & 36 & 0.8375 & 0.0522 & 0.8055 \\
\hline MILWAUKEE & MILWAUKEE & MILWAUKEE & $85-95$ & 759 & 0.3609 & -0.0648 & 0.0000 \\
\hline TARPON SPRINGS & PINELLAS & IO & $\mathrm{N} / \mathrm{A}$ & $\mathrm{N} / \mathrm{A}$ & $\mathrm{N} / \mathrm{A}$ & $\mathrm{N} / \mathrm{A}$ & $\mathrm{N} / \mathrm{A}$ \\
\hline${ }^{\star}{ }^{M}$ ATHER A.F.B. & SACRAMENTO & SACRAMENTO & $76-81$ & 144 & 0.1836 & -0.0301 & 0.7654 \\
\hline *MATHER A.F.B. & SACRAMENTO & SACRAMENTO & $82-84$ & 186 & 0.0747 & 0.2565 & 0.1498 \\
\hline *MATHER A.F.B. & SACRAMENTO & SACRAMENTO & $85-87$ & 433 & 0.1190 & 0.1041 & 0.1240 \\
\hline *MATHER A.F.B. & SACRAMENTO & SACRAMENTO & $88-93$ & 1017 & 0.4090 & 0.1919 & 0.0000 \\
\hline *MATHER A.F.B. & SACRAMENTO & SACRAMENTO & $94-96$ & 421 & 0.6075 & 0.1952 & 0.0000 \\
\hline MCCLELLAN A.F.B. & SACRAMENTO & SACRAMENTO & $76-79$ & 91 & 0.5687 & 0.4450 & 0.0005 \\
\hline MCCLELLAN A.F.B. & SACRAMENTO & SACRAMENTO & $80-84$ & 385 & 0.2852 & 0.3184 & 0.0270 \\
\hline MCCLELLAN A.F.B. & SACRAMENTO & SACRAMENTO & $85-87$ & 537 & 0.3557 & 0.0011 & 0.9926 \\
\hline MCCLELLAN A.F.B. & SACRAMENTO & SACRAMENTO & $88-93$ & 1732 & 0.4840 & 0.1868 & 0.0001 \\
\hline MCCLELLAN A.F.B. & SACRAMENTO & SACRAMENTO & $94-96$ & 612 & 0.4958 & 0.1209 & 0.1194 \\
\hline
\end{tabular}




\begin{tabular}{|c|c|c|c|c|c|c|c|}
\hline RANCHO CORDOVA & SACRAMENTO & IO & $\mathrm{N} / \mathrm{A}$ & $\mathrm{N} / \mathrm{A}$ & $\mathrm{N} / \mathrm{A}$ & $\mathrm{N} / \mathrm{A}$ & $\mathrm{N} / \mathrm{A}$ \\
\hline SACRAMENTO (ARMY DEPOT) & SACRAMENTO & SACRAMENTO & $75-78$ & 123 & 0.7539 & 0.0445 & 0.2895 \\
\hline SACRAMENTO (ARMY DEPOT) & SACRAMENTO & SACRAMENTO & $79-84$ & 428 & 0.1392 & 0.1826 & 0.0139 \\
\hline SACRAMENTO (ARMY DEPOT) & SACRAMENTO & SACRAMENTO & $85-87$ & 529 & 0.2470 & 0.0652 & 0.2629 \\
\hline SACRAMENTO (ARMY DEPOT) & SACRAMENTO & SACRAMENTO & $88-90$ & 1090 & 0.4078 & 0.0344 & 0.1528 \\
\hline SACRAMENTO (ARMY DEPOT) & SACRAMENTO & SACRAMENTO & 91-96 & 1428 & 0.5751 & 0.0961 & 0.0000 \\
\hline SACRAMENTO (JIBBOOM . . . ) & SACRAMENTO & SACRAMENTO & $76-80$ & 77 & 0.5145 & -0.1403 & 0.6388 \\
\hline SACRAMENTO (JIBBOOM. . . ) & SACRAMENTO & SACRAMENTO & $81-82$ & 50 & 0.4212 & 0.3101 & 0.3806 \\
\hline SACRAMENTO (JIBBOOM. . . ) & SACRAMENTO & SACRAMENTO & 83 & 53 & 0.4621 & -0.6164 & 0.2599 \\
\hline SACRAMENTO (JIBBOOM. . . ) & SACRAMENTO & SACRAMENTO & 84 & 73 & 0.5163 & 0.0297 & 0.9272 \\
\hline SACRAMENTO (JIBBOOM. . . ) & SACRAMENTO & SACRAMENTO & $85-87^{\star}$ & 369 & 0.4159 & 0.1870 & 0.2526 \\
\hline SACRAMENTO (JIBBOOM . . . ) & SACRAMENTO & SACRAMENTO & $88-96$ & 1576 & 0.5633 & 0.0042 & 0.9446 \\
\hline CAMP PENDLETON & SAN DIEGO & (NO DATA) & $\mathrm{N} / \mathrm{A}$ & $\mathrm{N} / \mathrm{A}$ & $\mathrm{N} / \mathrm{A}$ & $\mathrm{N} / \mathrm{A}$ & $\mathrm{N} / \mathrm{A}$ \\
\hline ALVISO & SANTA CLARA & I0 & $\mathrm{N} / \mathrm{A}$ & $\mathrm{N} / \mathrm{A}$ & $\mathrm{N} / \mathrm{A}$ & $\mathrm{N} / \mathrm{A}$ & $\mathrm{N} / \mathrm{A}$ \\
\hline CUPERTINO & SANTA CLARA & SAN JOSE & $73-85$ & 577 & 0.8399 & -0.0372 & 0.5254 \\
\hline CUPERTINO & SANTA CLARA & SAN JOSE & $86-87$ & 233 & 0.1411 & -0.0711 & 0.7222 \\
\hline CUPERTINO & SANTA CLARA & SAN JOSE & $88-90$ & 397 & 0.3773 & 0.0775 & 0.3662 \\
\hline CUPERTINO & SANTA CLARA & SAN JOSE & $91-92^{*}$ & 369 & 0.2333 & -0.0650 & 0.5079 \\
\hline CUPERTINO & SANTA CLARA & SAN JOSE & $93-96$ & 671 & 0.6228 & 0.0443 & 0.1476 \\
\hline MT. VIEW (CTS PRINTEX....) & SANTA CLARA & PALO ALTO & $71-86$ & 95 & 0.9232 & -0.0315 & 0.8433 \\
\hline MT. VIEW (CTS PRINTEX....) & SANTA CLARA & PALO ALTO & 87 & $13^{*}$ & $\mathrm{~N} / \mathrm{A}$ & $\mathrm{N} / \mathrm{A}$ & $\mathrm{N} / \mathrm{A}$ \\
\hline MT. VIEW (CTS PRINTEX....) & SANTA CLARA & PALO ALTO & $88-89$ & 21 & 0.9375 & 0.0405 & 0.6786 \\
\hline MT. VIEW (CTS PRINTEX....) & SANTA CLARA & PALO ALTO & $90-91^{*}$ & 35 & 0.7038 & 0.5778 & 0.0000 \\
\hline MT. VIEW (CTS PRINTEX....) & SANTA CLARA & PALO ALTO & $92-96$ & 88 & 0.7431 & 0.1928 & 0.0136 \\
\hline MT. VIEW (FAIRCHILD . . .) & SANTA CLARA & I0 & $\mathrm{N} / \mathrm{A}$ & $\mathrm{N} / \mathrm{A}$ & $\mathrm{N} / \mathrm{A}$ & $\mathrm{N} / \mathrm{A}$ & $\mathrm{N} / \mathrm{A}$ \\
\hline MT. VIEW ( INTEL . . . ) & SANTA CLARA & MOUNTAIN VIEW & $73-80$ & 68 & 0.9363 & -0.1894 & 0.4735 \\
\hline MT. VIEW (INTEL. . . .) & SANTA CLARA & MOUNTAIN VIEW & $81-84$ & $15^{*}$ & $\mathrm{~N} / \mathrm{A}$ & $\mathrm{N} / \mathrm{A}$ & $\mathrm{N} / \mathrm{A}$ \\
\hline$($ INTEL ... ) & SANTA CLARA & MOUNTAIN & 85 & $11^{*}$ & $\mathrm{~N} / \mathrm{A}$ & $\mathrm{N} / \mathrm{A}$ & $\mathrm{N} / \mathrm{A}$ \\
\hline$($ INTEL ....) & SANTA CLARA & MOUNTAIN VIEW & $86-96$ & 341 & 0.8077 & 0.1153 & 0.1038 \\
\hline$($ JASCO ... ) & SANTA CLARA & LOS ALTOS & $72-86$ & 473 & 0.7771 & -0.0008 & 0.9890 \\
\hline$($ JASCO ... $)$ & SANTA CLARA & LOS ALTOS & 87 & 82 & 0.7121 & -0.0475 & 0.3890 \\
\hline (JASCO...) & SANTA CLARA & LOS ALTOS & $88-89$ & 150 & 0.5798 & -0.0841 & 0.0468 \\
\hline$($ JASCO ... & SANTA CLARA & LOS ALTOS & $90-96$ & 785 & 0.5682 & 0.0418 & 0.0746 \\
\hline (RAYTHEON . . . ) & SANTA CLARA & I0 & $\mathrm{N} / \mathrm{A}$ & $\mathrm{N} / \mathrm{A}$ & $\mathrm{N} / \mathrm{A}$ & $\mathrm{N} / \mathrm{A}$ & $\mathrm{N} / \mathrm{A}$ \\
\hline (SPECTRA) & SANTA CLARA & IO & $\mathrm{N} / \mathrm{A}$ & $\mathrm{N} / \mathrm{A}$ & $\mathrm{N} / \mathrm{A}$ & $\mathrm{N} / \mathrm{A}$ & $\mathrm{N} / \mathrm{A}$ \\
\hline MT. VIEW (TELEDYNE) & SANTA CLARA & IO & $\mathrm{N} / \mathrm{A}$ & $\mathrm{N} / \mathrm{A}$ & $\mathrm{N} / \mathrm{A}$ & $\mathrm{N} / \mathrm{A}$ & $\mathrm{N} / \mathrm{A}$ \\
\hline PALO ALTO & SANTA CLARA & PALO ALTO & $72-83$ & 470 & 0.7387 & -0.0845 & 0.0700 \\
\hline PALO ALTO & SANTA CLARA & PALO ALTO & $84-87$ & 380 & 0.2823 & -0.0439 & 0.5848 \\
\hline
\end{tabular}




\begin{tabular}{|c|c|c|c|c|c|c|c|c|}
\hline PALO ALTO & SANTA & CLARA & PALO ALTO & $88-89$ & 242 & 0.4848 & 0.1428 & 0.0065 \\
\hline$\overline{\text { PALO ALTO }}$ & SANTA & $\overline{C L A R A}$ & PALO ALTO & $90-96$ & 1324 & 0.6171 & 0.0119 & 0.5473 \\
\hline${ }^{*}$ SAN JOSE (FAIRCHILD...) & SANTA & CLARA & SAN JOSE & $72-79$ & 667 & 0.8331 & -0.0191 & 0.0215 \\
\hline *SAN JOSE (FAIRCHILD....) & SANTA & CLARA & SAN JOSE & $80-84$ & 357 & 0.0799 & 0.0095 & 0.7627 \\
\hline *SAN JOSE (FAIRCHILD....) & SANTA & CLARA & SAN JOSE & $85-89$ & 1415 & 0.3419 & -0.0217 & 0.0867 \\
\hline (FAIRCHILD. . . ) & SANTA & CLARA & SAN JOSE & $90-92^{*}$ & 1232 & 0.1061 & -0.0527 & 0.0001 \\
\hline *SAN JOSE (FAIRCHILD...) & SANTA & CLARA & SAN JOSE & $93-96$ & 1681 & 0.5967 & -0.0186 & 0.0000 \\
\hline SAN JOSE (LORENTZ....) & SANTA & CLARA & SAN JOSE & $72-80$ & 1183 & 0.7844 & 0.0884 & 0.0002 \\
\hline SAN JOSE (LORENTZ....) & SANTA & CLARA & SAN JOSE & $81-84$ & 271 & 0.2473 & 0.1018 & 0.3863 \\
\hline SAN JOSE (LORENTZ....) & SANTA & CLARA & SAN JOSE & $85-89$ & 1712 & 0.3580 & 0.0924 & 0.0102 \\
\hline ( LORENTZ....) & SANTA & CLARA & SAN JOSE & $90-91$ & 1038 & 0.1879 & 0.0397 & 0.4300 \\
\hline SAN JOSE (LORENTZ ... ) & SANTA & CLARA & SAN JOSE & $92-96$ & 2966 & 0.3915 & 0.0789 & 0.0000 \\
\hline *SANTA CLARA (INTEL CORP . . . ) & SANTA & CLARA & SANTA CLARA & $72-80$ & 172 & 0.8042 & 0.1118 & 0.0092 \\
\hline *SANTA CLARA (INTEL CORP ....) & SANTA & CLARA & SANTA CLARA & $81-84$ & 50 & 0.2589 & 0.0878 & 0.6794 \\
\hline *SANTA CLARA ( INTEL CORP . . . ) & SANTA & CLARA & SANTA CLARA & 85 & $12^{*}$ & $\mathrm{~N} / \mathrm{A}$ & $\mathrm{N} / \mathrm{A}$ & $\mathrm{N} / \mathrm{A}$ \\
\hline *SANTA CLARA (INTEL CORP....) & SANTA & CLARA & SANTA CLARA & $86-90$ & 226 & 0.3507 & -0.0161 & 0.8686 \\
\hline *SANTA CLARA ( INTEL CORP . . .) & SANTA & CLARA & SANTA CLARA & $91-92^{*}$ & 180 & 0.0851 & 0.1343 & 0.2421 \\
\hline *SANTA CLARA (INTEL CORP ... .) & SANTA & CLARA & SANTA CLARA & $93-96$ & 320 & 0.2476 & 0.0376 & 0.3461 \\
\hline SANTA CLARA (INTEL MAG... .) & SANTA & CLARA & I0 & $\mathrm{N} / \mathrm{A}$ & $\mathrm{N} / \mathrm{A}$ & $\mathrm{N} / \mathrm{A}$ & $\mathrm{N} / \mathrm{A}$ & $\mathrm{N} / \mathrm{A}$ \\
\hline SANTA CLARA (NATIONAL...) & SANTA & CLARA & SUNNYVALE & $73-80$ & 91 & 0.9115 & -0.1726 & 0.0322 \\
\hline SANTA CLARA (NATIONAL ....) & SANTA & CLARA & SUNNYVALE & $81-84$ & $15^{*}$ & $\mathrm{~N} / \mathrm{A}$ & $\mathrm{N} / \mathrm{A}$ & $\mathrm{N} / \mathrm{A}$ \\
\hline SANTA CLARA (NATIONAL ....) & SANTA & CLARA & SUNNYVALE & $85-87$ & 53 & 0.3914 & -0.1091 & 0.5545 \\
\hline SANTA CLARA (NATIONAL ... .) & SANTA & CLARA & SUNNYVALE & $88-91$ & 93 & 0.5393 & 0.0667 & 0.3393 \\
\hline SANTA CLARA (NATIONAL ....) & SANTA & CLARA & SUNNYVALE & $92-96$ & 162 & 0.7334 & 0.0458 & 0.3010 \\
\hline SANTA CLARA (SYNERTEK. . . ) & SANTA & CLARA & SANTA CLARA & $72-85$ & 158 & 0.6524 & 0.3638 & 0.0298 \\
\hline SANTA CLARA (SYNERTEK. . . ) & SANTA & CLARA & SANTA CLARA & $86-87$ & 58 & 0.0885 & -0.3466 & 0.2834 \\
\hline SANTA CLARA (SYNERTEK. . . ) & SANTA & CLARA & SANTA CLARA & $88-89$ & 51 & 0.6342 & 0.0699 & 0.5913 \\
\hline SANTA CLARA (SYNERTEK. . . ) & SANTA & CLARA & SANTA CLARA & $90-91^{*}$ & 60 & -0.0793 & 0.2804 & 0.4426 \\
\hline SANTA CLARA (SYNERTEK. . . ) & SANTA & CLARA & SANTA CLARA & $92-96$ & 166 & 0.1037 & 0.1609 & 0.1865 \\
\hline SUNNYVALE (ADVANCED . . . ) & SANTA & CLARA & SUNNYVALE & $72-84$ & 141 & 0.9465 & -0.0359 & 0.0816 \\
\hline SUNNYVALE (ADVANCED ....) & SANTA & CLARA & SUNNYVALE & $85-87$ & 76 & 0.0618 & -0.0828 & 0.3193 \\
\hline SUNNYVALE (ADVANCED . . . ) & SANTA & CLARA & SUNNYVALE & $88-90$ & 99 & -0.0039 & -0.0552 & 0.7517 \\
\hline (ADVANCED . . . ) & SANTA & CLARA & SUNNYVALE & $91^{\star}$ & 44 & -0.0291 & 0.1244 & 0.6323 \\
\hline SUNNYVALE (ADVANCED . . . ) & SANTA & CLARA & SUNNYVALE & $92-96$ & 255 & 0.0767 & -0.0158 & 0.4644 \\
\hline SUNNYVALE (MONOLITHIC ... ) & SANTA & CLARA & I0 & $\mathrm{N} / \mathrm{A}$ & $\mathrm{N} / \mathrm{A}$ & $\mathrm{N} / \mathrm{A}$ & $\mathrm{N} / \mathrm{A}$ & $\mathrm{N} / \mathrm{A}$ \\
\hline SUNNYVALE (TRW... ) & SANTA & CLARA & I0 & $\mathrm{N} / \mathrm{A}$ & $\mathrm{N} / \mathrm{A}$ & $\mathrm{N} / \mathrm{A}$ & $\mathrm{N} / \mathrm{A}$ & $\mathrm{N} / \mathrm{A}$ \\
\hline *SUNNYVALE (WESTING....) & SANTA & CLARA & SUNNYVALE & $72-80$ & 377 & 0.8331 & 0.0590 & 0.0184 \\
\hline *SUNNYVALE (WESTING...) & SANTA & CLARA & SUNNYVALE & $81-84$ & 89 & 0.3802 & -0.1772 & 0.0496 \\
\hline
\end{tabular}




\begin{tabular}{|c|c|c|c|c|c|c|c|}
\hline${ }^{*}$ SUNNYVALE (WESTING . . . ) & SANTA CLARA & SUNNYVALE & 85 & 48 & $\odot .8101$ & -0.0247 & 0.6011 \\
\hline${ }^{*}$ SUNNYVALE (WESTING . . . ) & SANTA CLARA & SUNNYVALE & $86-96$ & 1601 & 0.6793 & 0.0995 & 0.0000 \\
\hline BRIDGETON & ST. LOUIS & BRIDGETON & 79 & 40 & 0.7549 & -0.0797 & 0.6344 \\
\hline BRIDGETON & ST. LOUIS & BRIDGETON & $80-89$ & 846 & 0.7571 & 0.1160 & 0.0000 \\
\hline BRIDGETON & ST. LOUIS & BRIDGETON & 90 & 104 & 0.5904 & 0.6902 & 0.0000 \\
\hline BRIDGETON & ST. LOUIS & BRIDGETON & $91-94$ & 593 & 0.6801 & 0.3467 & 0.0000 \\
\hline${ }^{\star}$ ELLISVILLE & ST. LOUIS & BALLWIN & $79-80$ & 68 & 0.5151 & 0.0422 & 0.6432 \\
\hline${ }^{*} E L L I S V I L L E$ & ST. LOUIS & BALLWIN & 81 & 44 & 0.7072 & -0.1832 & 0.0003 \\
\hline${ }^{\star} E L L I S V I L L E$ & ST. LOUIS & $B A L L W I N$ & $82-83$ & 110 & 0.7090 & -0.1288 & 0.0013 \\
\hline${ }^{\text {*ELLISVILLE }}$ & ST. LOUIS & $B A L L W I N$ & 84-86* & 282 & 0.6514 & -0.1734 & 0.0000 \\
\hline${ }^{\text {*ELLISVILLE }}$ & ST. LOUIS & BALLWIN & $87-94$ & 2555 & 0.6184 & -0.1805 & 0.0000 \\
\hline TIMES BEACH & ST. LOUIS & EUREKA & $79-81$ & 41 & 0.8785 & 0.4294 & 0.0000 \\
\hline TIMES BEACH & ST. LOUIS & EUREKA & 82 & 9 & 0.9921 & 0.5130 & 0.3271 \\
\hline TIMES BEACH & ST. LOUIS & EUREKA & 83 & 15 & 0.6762 & 0.0306 & 0.5747 \\
\hline TIMES BEACH & ST. LOUIS & EUREKA & $84-94$ & 514 & 0.6137 & 0.2602 & 0.0000 \\
\hline VALLEY PARK TCE & ST. LOUIS & $B A L L W I N$ & $79-84$ & 487 & 0.5985 & -0.1150 & 0.0055 \\
\hline VALLEY PARK TCE & ST. LOUIS & $B A L L W I N$ & 85 & 128 & 0.6598 & -0.1744 & 0.0084 \\
\hline VALLEY PARK TCE & ST. LOUIS & $B A L L W I N$ & 86 & 144 & 0.5371 & -0.2217 & 0.0136 \\
\hline VALLEY PARK TCE & ST. LOUIS & BALLWIN & $87-94$ & 2471 & 0.5192 & -0.2741 & 0.0000 \\
\hline
\end{tabular}

BOLD TYPE denotes period where LNDIST is positive and significant.

ITALICIZED BOLD TYPE denotes period where LNDIST is negative and significant.

REGULAR TYPE denotes period where LNDIST is insignificant.

* on TIME denotes cleanup of site completed by end of period

* on SITE denotes model doesn't include census data

* on $\mathrm{N}$ denotes model is biased due to insufficient observations

$/ /$ Uses dffits $=2$

// All OBS are < 3 miles from site 


\section{TABLE 4}

Marginal Benefit of Increased Distance from NPL Site

(Applied to the 18 sites possessing positive/significant coefficients on LNDIST for the period following final listing)

County

Broward
Broward
Broward
Broward
Broward
Dade
Dade
Dade
Hamilton
Hills.
King
King
Sacto.
Sacto.
Santa Clara
Santa Clara
St. Louis
St. Louis

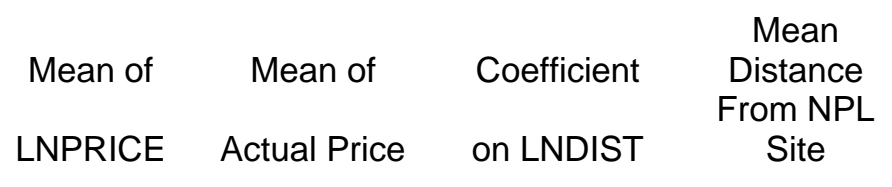

$\begin{array}{cccc}11.2188 & 74518.29037 & 0.063825 & 1.477 \\ 10.9672 & 57942.12145 & 0.077045 & 1.935 \\ 11.27213 & 78600.22822 & 0.048643 & 2.123 \\ 10.81764 & 49893.19435 & 1.762094 & 1.914 \\ 11.71793 & 122753.0481 & 0.238956 & 1.939 \\ 11.47245 & 96033.26107 & 0.042167 & 1.838 \\ 11.36375 & 86141.78505 & 0.355623 & 2.347 \\ 11.23835 & 75989.45672 & 0.015581 & 1.645 \\ 11.15282 & 69760.26681 & 0.034725 & 2.064 \\ 10.4148 & 33349.5611 & 0.67551 & 1.259 \\ 11.59545 & 108602.5187 & 0.037355 & 1.038 \\ 11.42214 & 91321.3497 & 0.127036 & 2.402 \\ 11.60094 & 109200.3862 & 0.191899 & 2.209 \\ 11.51262 & 99969.44612 & 0.186841 & 2.484 \\ 12.92274 & 409519.5264 & 0.577762 & 1.374 \\ 12.5094 & 270871.5139 & 0.099505 & 1.568 \\ 11.48799 & 97537.27384 & 0.346747 & 2.149 \\ 11.35264 & 85190.04652 & 0.260202 & 1.824\end{array}$

*Lacks Census Vars.

All numbers are for the Post-Final Period 
TABLE 5

Meta Analysis Variables and Descriptive Statistics

\begin{tabular}{|c|c|c|}
\hline Name & Description & $\begin{array}{l}\text { Means and Standard } \\
\text { Deviations }\end{array}$ \\
\hline FOURTH & $\begin{array}{l}=1 \text { if estimated coefficient on } \\
\text { LNDIST was positive and } \\
\text { significant in period after NPL } \\
\text { listing occurred }\end{array}$ & $\begin{aligned} \text { Mean } & =.327 \\
\text { STD } & =.474\end{aligned}$ \\
\hline SIZE & Size of site (in acres) & $\begin{aligned} \text { Mean } & =269.5 ; \\
\text { STD } & =906.8\end{aligned}$ \\
\hline MANU & $=1$ if site is a manufacturing site & $\begin{aligned} \text { Mean } & =.473 \\
\text { STD } & =.504\end{aligned}$ \\
\hline LANDFILL & $=1$ if site is a landfill & $\begin{aligned} \text { Mean } & =.200 \\
\text { STD } & =.404\end{aligned}$ \\
\hline WASTE & $\begin{array}{l}=1 \text { if site is refiner/processor of } \\
\text { waste products }\end{array}$ & $\begin{aligned} \text { Mean } & =.236 \\
\text { STD } & =.429\end{aligned}$ \\
\hline OTHER & $=1$ if site is other (military) & $\begin{aligned} \text { Mean } & =.091 \\
\text { STD } & =.290\end{aligned}$ \\
\hline NUMOBS & $\begin{array}{l}\text { Number of observations in hedonic } \\
\text { regression }\end{array}$ & $\begin{aligned} \text { Mean } & =856.6 \\
\text { STD } & =814.3\end{aligned}$ \\
\hline ADJR2 & Adjusted $\mathrm{R}^{2}$ from hedonic regression & $\begin{aligned} \text { Mean } & =.4930 \\
\text { STD } & =.2056\end{aligned}$ \\
\hline MEDDIST & $\begin{array}{l}\text { Median distance from site in } \\
\text { hedonic regression }\end{array}$ & $\begin{aligned} \text { Mean } & =1.896 \\
\text { STD } & =.498\end{aligned}$ \\
\hline WESTC & $\begin{array}{l}=1 \text { if site is in California or } \\
\text { Washington }\end{array}$ & $\begin{aligned} \text { Mean } & =.436 \\
\text { STD } & =.501\end{aligned}$ \\
\hline FLORIDA & $=1$ if site is in Florida & $\begin{aligned} \text { Mean } & =.418 \\
\text { STD } & =.498\end{aligned}$ \\
\hline OTHERLOC & $\begin{array}{c}=1 \text { if site is not on West Coast or in } \\
\text { Florida }\end{array}$ & $\begin{aligned} \text { Mean } & =.146 \\
\text { STD } & =.356\end{aligned}$ \\
\hline CENSUS & $\begin{array}{c}=1 \text { if hedonic regression included } \\
\text { census tract level variables }\end{array}$ & $\begin{aligned} \text { Mean } & =.782 ; \\
\text { STD } & =.417\end{aligned}$ \\
\hline VACANCY & $\begin{array}{c}\text { Average vacancy rate of county } \\
\text { from 1971-1996 according to EPA } \\
\text { data set }\end{array}$ & $\begin{aligned} \text { Mean } & =5.36 ; \\
\text { STD } & =2.42\end{aligned}$ \\
\hline BLUECOL & $\begin{array}{c}\text { Percent of blue-collar residents in } \\
\text { county from 1971-1996 according to } \\
\text { EPA data set }\end{array}$ & $\begin{array}{c}\text { Mean }=35.66 \\
\text { STD }=3.66\end{array}$ \\
\hline PRIOREQ3 & $\begin{array}{l}=1 \text { if coefficient on LNDIST was } \\
\text { positive and significant in any of the } \\
\text { first three periods }\end{array}$ & $\begin{aligned} \text { Mean } & =.509 ; \\
\text { STD } & =.505\end{aligned}$ \\
\hline
\end{tabular}


TABLE 6

Results from Meta Analysis

Dependent Variable: FOURTH

Method: ML - Binary Probit

Date: 08/13/03 Time: 15:59

Sample: 357

Included observations: 55

Convergence achieved after 8 iterations

Covariance matrix computed using second derivatives

\begin{tabular}{|c|c|c|c|c|}
\hline Variable & Coefficient & Std. Error & z-Statistic & Prob. \\
\hline C & 5.953490 & 6.227215 & 0.956044 & 0.3391 \\
\hline SIZE & 0.001183 & 0.000804 & 1.471819 & 0.1411 \\
\hline MANU & 1.845044 & 1.888272 & 0.977108 & 0.3285 \\
\hline LANDFILL & 0.894333 & 1.870207 & 0.478200 & 0.6325 \\
\hline WASTE & 1.297032 & 1.964100 & 0.660369 & 0.5090 \\
\hline NUMOBS & 0.000518 & 0.000276 & 1.878694 & 0.0603 \\
\hline ADJR2 & 3127 & 1.660904 & 1.717815 & 0.0858 \\
\hline MEDDIST & 4453 & 0.545832 & -0.7 & 0.4477 \\
\hline WESTC & -0.4 & 1425 & -0.4 & 0.6188 \\
\hline FLORIDA & 1.2 & 2277 & 0.6 & 0.5011 \\
\hline CENSUS & 0.568296 & 0.728411 & 0.780186 & 0.4353 \\
\hline VACANCY & 0.223208 & 0.207156 & 1.077489 & 0.2813 \\
\hline BLUECOL & -0.33 & 032 & -1.6 & 0.1030 \\
\hline PRIOREQ3 & 1.2 & 0.566360 & 2.231534 & 0.0256 \\
\hline Mean dependent $\mathrm{V}$ & 0.327273 & \multicolumn{2}{|c|}{ S.D. dependent var } & 0.473542 \\
\hline S.E. of regression & 778 & \multicolumn{2}{|c|}{ Akaike info criterion } & 1.264067 \\
\hline Sum squared resid & 6.98 & \multirow{2}{*}{\multicolumn{2}{|c|}{$\begin{array}{l}\text { Schwarz criterion } \\
\text { Hannan-Ouinn criter }\end{array}$}} & 1.775025 \\
\hline Log likelihood & -20.76185 & & & 1.461659 \\
\hline Restr. log likelihood & -34.77267 & \multicolumn{2}{|c|}{ Avg. log likelihood } & -0.377488 \\
\hline LR statistic (13 df) & 28.02165 & \multirow{2}{*}{\multicolumn{2}{|c|}{ McFadden R-squared }} & 0.402926 \\
\hline Probability(LR stat) & 0.008987 & & & \\
\hline Obs with Dep=0 & 37 & \multirow{2}{*}{\multicolumn{2}{|c|}{ Total obs }} & 55 \\
\hline Obs with Dep=1 & 18 & & & \\
\hline
\end{tabular}

